\title{
COLD SPRING HARBOR
}

\section{MONOGRAPHS.}

\author{
VII.
}

THE FRESH WATER CYCLOPS OF LONG ISLAND.

BY

ESTHER F. BYRNES, Ph.D.

WITH FIFTEEN PLATES

PUBLISHED BY

The Brooklyn Institute of Arts And Sclexices.

BROOKLYN, N. Y.

IYARCH, IgOg.

Issued February $17^{\text {th, }}$, 909 



\section{COLD SPRING HARBOR}

\section{MONOGRAPHS.}

VII.

THE FRESH WATER CYCLOPS OF LONG ISLAND.

$13 \%$

ESTHER F. BYRNES, Ph. D.

WITH FIFTEEN PLATES

PUBI.ISHED BY

ThE BroOKINN INSTITUTE of ARTS ANI SCIExCES.

BROOKLYN, N. Y.

MARCII, IgO9.

Issued February i 7 th, I 909 



\title{
COLD SPRING HARBOR MONOGRAPHS. VII.
}

FRESH WATER CYCLOPS OF LONG ISLAND.

\author{
ESTHER F. BYRNES.
}

TABLE OF CONTENTS.

PAGE

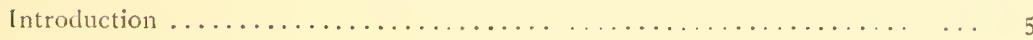

List of Species Studied $\ldots \ldots \ldots \ldots \ldots \ldots \ldots \ldots \ldots \ldots \ldots \ldots \ldots \ldots \ldots \ldots$

Cyclops ater-Herrick ... ....................... 5

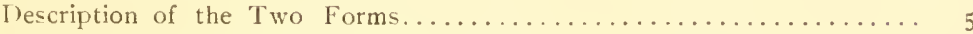

Variations in C. ater.......................... 7

Cyclops signatus $-\mathrm{KocH} \ldots \ldots \ldots \ldots \ldots \ldots \ldots \ldots \ldots \ldots \ldots \ldots \ldots \ldots$

General Description............................ s

Cyclops signatus, var, coronatus ..................... 9

Transitional Stages of C. signatus, coronatus................ 1o

Cyclops signatus, var, annulicornis ..................... 10

Younger Stages of $\mathrm{C}$. signatus, var. annulicornis ............ I I

Variations in C. signatus, var, annulicornis $\ldots \ldots \ldots \ldots \ldots \ldots \ldots \ldots \ldots$

Cyclops Americanus-Marsh $\ldots \ldots \ldots \ldots \ldots \ldots \ldots \ldots \ldots \ldots \ldots \ldots \ldots \ldots \ldots \ldots$

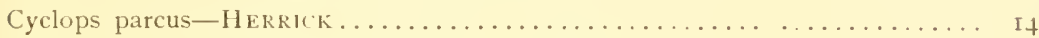

Cyclops brevispinosus-IIERRICK ................... I6

General Description........................... 16

Heterogenous Form......................... I 7

Variations. . . . . . . . . . . .

Cyclops ingens-HerRick ?......................... 22

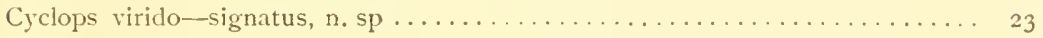

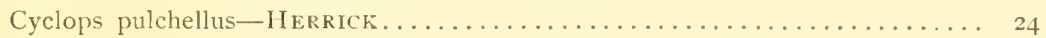

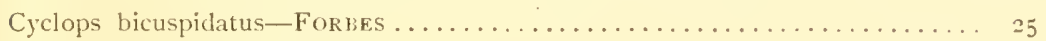

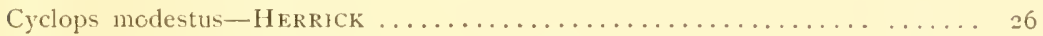

Cyclops serrulatus-Forbes......................... 27

Cyclops tluviatilis-Herrick........................ 28

Cyclops biculor-SAks.............................. 29

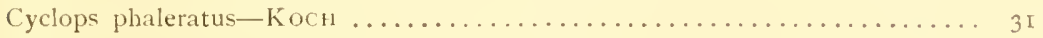

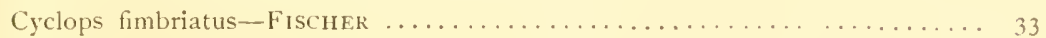

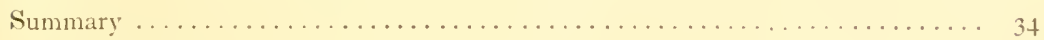

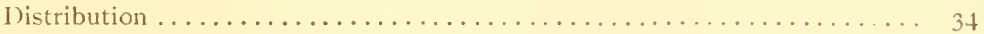

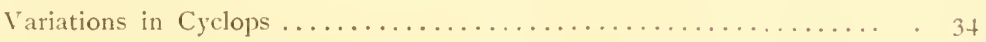

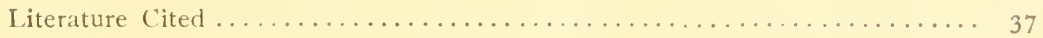




\section{LIST OF SPECIES STUDIED.}

\begin{tabular}{|c|c|c|}
\hline & & I \\
\hline signatus, coronatus-KoCH. C. fuscus-JURINE ... & S & II, II \\
\hline signatus annulicornis, C. albidus-JURINE. & Io & IV \\
\hline Americanus-MARsH. C. insectus-Forlies & 13 & $\mathrm{~V}$ \\
\hline parcus-НЕRRICK ...... & 14 & VI, XI \\
\hline IS-HERRICK. & I 6 & $\mathrm{r}, \mathrm{VII}$ \\
\hline RICK? & 22 & IIII \\
\hline us, n. sp.... & 23 & IX \\
\hline$-\mathrm{H}_{1}$ & 24 & $\mathrm{X}$ \\
\hline datus-FORBES. & 25 & $\mathrm{x}$ \\
\hline IS-HERRICK... & 26 & $X I$ \\
\hline 1S-FORBES.... & 27 & XII \\
\hline S-HERRICK. . & $2 S$ & X V \\
\hline -SARS ...... & 29 & XIII \\
\hline $\mathrm{s}-\mathrm{Koc} 11$ & & $\mathrm{XIV}$ \\
\hline -Fischer. & & IV \\
\hline
\end{tabular}




\section{Introduction.}

The observations recorded in this Monograph have extended over several years and have been made with special reference to the variability of the Cyclops of fresh water. While in many instances too few individuals of a species have been studied to permit of the drawing of conclusions in regard to the tendencies of the species to vary in any given direction, special care has been taken to record such differences as have been observed between the Long Island forms and those described and figured by earlier American authors.

The plates illustrate such forms as have been seen mainly in the waters of the western section of Long Island.

The figures have all been drawn to the same scale in order to preserve the relative sizes of the various forms, and care has been taken to reproduce accurately all such details as have been considered. Nmmerous experiments have been made in the rearing of certain species to test the relationship of closely allied forms and some few relationships have been clearly established through this method which alone can be trusted to yield definite results among forms as varied as are the fresh water Cyclops.

This work has been carried on during two summers at Cold Spring Harbor, Long Island, at the Laboratory of the Brooklyn Institute of Arts and Sciences. My best thanks are due Professor C. B. Davenport, Director of the Laboratory, for having placed at my disposal the fullest facilities of the station, and for having read the manuscript.

\section{Cyclops Ater (Plate I).}

Description of the Trwo Forms.-Cyclops ater is one of the more common forms of Cyclops found at Cold Spring Harbor, Long Island. The adults present two distinct appearances; the distinctions are, however, linited to color, so far as my observations show.

The two forms were collected in localities subjected to widely different conditions. One form was found in pools of cold spring water, completely covered by a dense growth of duck weed. It 
was also collected along the borders of a shallow pond fed by the cold water from a woodland brook, and overgrown with water weeds along its banks.

This Cyclops was very deeply pigmented, especially on the cephalo-thorax, the posterior thoracic segments, the outer margins of the abdomen and the stylets. The outer rami of the swimming feet were deeply and uniformly pigmented. The inner rami of the fourth feet were quite colorless. This is the appendage to which the male attaches itself during copulation. The ovaries and the embryos of this Cyclops were almost colorless.

The second form of ater was taken from an unshaded pond where the shallow water became uniformly heated, and where the temperature was considerably higher than in the pools mentioned above. The Cyclops from this locality contained much less pigment and appeared banded, having dark lines across the thorax. The appearance of this form was made very striking by the bright orange color of the ovaries.

All the forms of ater agreed in the number of antennal segments, in the armature of the swimming feet and in the fifth foot, as well as in the general proportions of the body.

The number of hairs on the seventeen antennal segments of $\mathrm{C}$. ater, counting from the base is as follows: $8,4,2,6,4,2,2$, I, I, O, I, 2, O, I, 2, 3, 8 .

The armature of the terminal segments of the swimming feet is as follows:

\begin{tabular}{|c|c|c|c|c|c|c|c|c|}
\hline \multirow{2}{*}{$\frac{\text { Foor No............. }}{\text { Ramus, Outer or Inner. }}$} & \multicolumn{2}{|c|}{ I } & \multicolumn{2}{|c|}{ II } & \multicolumn{2}{|c|}{ III } & \multicolumn{2}{|c|}{$\mathrm{IV}^{\top}$} \\
\hline & 0 & I & 0 & I & $\mathrm{O}$ & I & $\mathrm{O}$ & I \\
\hline Outer Spines ... & 3 & 1 (sa) & 3 & 1 (sa) & 3 & 1 (sa) & 2 & 1 (sa) \\
\hline Apical Spines. & 1 & 1 & 1 & 1 & 1 & 1 & 1 & 2 \\
\hline Apical Seta... & 1 & 1 & 1 & 1 & 1 & 1 & 1 & 0 \\
\hline Inner Setæ.... & 3 & 3 & 4 & $t$ & 4 & 3 & $t$ & 2 \\
\hline
\end{tabular}

sa-seta in place of spine,

The setre are long and strongly developed and the spines are stout and distinctly serrated.

The fifth feet of ater are one-jointed and bear a well formed median spine, not always serrated and two long, slender setæe, 
one on the apex and one on the outer angle. The posterior margins, dorsal and ventral, of the last abdominal segment are serrated. The stylets are armed with four plumose setæe and two short hairs, often without barbs. While not a profusely hairy form, hairs are often present on the rami of the swimming feet of this species, particularly on the outer margins of the segments of the inner rami. The margins of the segments are often strongly serrated as well as hairy.

Herrick's notes on C. ater are very brief. He describes ater as "our most characteristic American species; color deep blue or gray; ovisacs pale." He also finds young with "a deep band of color crossing the thorax near the middle", but makes no mention of the color of the ovaries which is so striking that, had he observed it, he could hardly have failed to mention the fact in his writings.

Professor Marsh quotes Frofessor Reighard's description of $C$. atcr with which the banded form from Cold Spring IIarbor agrees very closely. He also observed the orange colored ovaries.

In the proportion of parts and in the armature of the appendages, the two forms agree; but, as in the case of $C$. scrulatus, the significance of the occurrence of differently colored ovaries with a uniformly different distribution of pigment needs further study. Vithout further acquaintance with the two forms, the differences are sufficiently striking to suggest that they might be well marked varieties.

Variations of C. Atcr.-.The Cold Spring Harbor forms of ater present little variation in their armature. They differ. however, from the forms described by Professor Herrick, who found the "setre all short and stout," whereas the setre are quite long and well formed in the ater found at Cold Spring Harbor. They differ also from the forms described by Professor Marsh in that they have a well formed spine in the apical position on the nuter ramus of the first foot, where Professor Marsh finds a seta. This outer "seta" on the apex of the onter ramus of the first font is, as Fig. 6, Plate I., shows, clearly a well formed seta on the median side and a spine on the outer margin. This shows that setie and spines are interchangeable and hence can be accorded little value in the determining of species.

As for the fifth font, the Cold Spring Harbor forms of $C$, ater 
agree with Professor Marsh's account in having a strong spine on the inner angle and two setre, one median and one on the outer angle. The median seta reaches to the posterior margin of the first abdominal segment. The setx may or may not be without hairs. Herrick observed "three subequal spines" on the distal margin of the fifth foot.

Cyclops atcr is one of the largest Cyclops seen in the Long Island waters. It represents a very well marked species, in which there appears to be but very little variation.

Associated with $C$. atcr is a little water mite belonging to the genus Arrhenurus. This fact was observed by Professor Marsh in 1895 and $I$ also have observed this Arrhenurus. It was first called to my attention by the fact that it and $\mathrm{C}$. ater resemble each other not only in size and color, but also in their manner of morement. C. ater does not dart through the water as do many of the Cyclops, but potters about with short jerk movements, thus greatly increasing its resemblance to the accompanying form. Further observation showed, however, that the water mites are not always dark like the Cyclops; sometimes they are mottled and sometimes bright red.

\section{Cyclops Signatus, KocH.}

General Description.-Cyclops signatus is one of the largest and most abundant species found at Cold Spring Harbor, attaining and often exceeding a length of $\mathrm{I} .5 \mathrm{~mm}$. The species is represented by two forms-coronatus and annulicornis-which occur side by side and closely resemble each other. The presence of these two forms with their transitional stages in the same locality offers not a little difficulty to the student who is unacquainted with the varietal characteristics of the species.

The species can readily be identified even in early stages by the presence of a two- jointed fifth foot, in which the outer basal segment bears on its outer angle, a seta without barbs or with barbs, according to age; and in which the distal segment bears a median seta and two lateral spines also with or without serrations according to age.

The antenne in the adults contain seventeen segments and reach to the abdomen. The armature of these segments is extremely 
constant; the typical number of liairs on each segment is indicated by the following series of figures, counting from the base: $8,4,2.6$, $4,2,2, \mathrm{I}, \mathrm{I}, \mathrm{O}, \mathrm{I}$, ?, O, I, 2, 2. 8.

The armature of the twelfth segment shows a tendency to vary; occasionally but one distal hair is present; again two are present, in which case one is larger than the other.

Cyclops Signatus, war. Coronatus* (Plates II., III.).-This form (also known as Cyclops fusucs, JuRINE) has a short second joint in the antennule, Pl. II., Fig. 3, serrations in the hyaline prate on the two distal segments of the antenna (Fig. 4), a short. almost square, basal segment in the fifth foot (Fig. 5), and numerous hairs on the inner margins of the caudal stylets (Fig. 6). The notches in the hyaline plate of the antenne form gradually and may or may not be present. In Fig. 4 , they are seen on the last segment only.

The adult armature of the terminal segments of the swimming feet is as follows:

\begin{tabular}{|c|c|c|c|c|c|c|c|c|}
\hline \multirow{2}{*}{$\begin{array}{l}\text { Foot No............. } \\
\text { Kamus, Outer or Inner. . }\end{array}$} & \multicolumn{2}{|c|}{ I } & \multicolumn{2}{|c|}{ II } & \multicolumn{2}{|c|}{ I I I } & \multicolumn{2}{|c|}{15} \\
\hline & 0 & I & () & I & 0 & I & $\mathrm{O}$ & 1 \\
\hline Outer spines ... & 3 & 1 (sa) & 3 & 1 (sa) & 3 & 1 (sat & 2 & 1 (sa) \\
\hline Apical Spines & 1 & 1 & 1 & I & 1 & 1 & 1 & 1 \\
\hline Ipical Seta & 1 & 1 & 1 & 1 & 1 & 1 & 1 & 1 \\
\hline Inner Setr ......... & 3 & 3 & 1 & 3 & $t$ & 3 & 4 & 2 \\
\hline
\end{tabular}
sa $=$ seta in place of spine.

The older forms of coronatus are usually densely pigmented, brown and blue tones prevailing. They often become very coarsely serrated and hairy. The ova are dark and the ovisacs are carried closely pressed to the abdomen.

Few striking variations have been observer in these forms. They

* I have used the more recent name, $C$. signatus, lariety coronatus, instead of the older name, C. fuscus. JuknNe, because it expresses more clearly the evidently close relationship that exists between (. signatus, variety coronatus, and the allied form, $C$. signatus, variety annulicornis, called $C$. albidus by Jurine. 
seem to belong to a fixed type, and agree very closely with the descriptions already given by earlier authors.

Transitional Stages of C. Signatus, Coronatus.-Accompanying the adult forms, are the later transitional stages of the species. These are conspicuous both for their size and numbers. Attention has been called elsewhere (Byrnes, I906) * to the constancy with which correlated characteristics occur in the young of Cyclops. Plate III, reproduces two of the more striking correlations. It shows that when the young have ten segments, or even nine in the antennx, they have two-jointed rami in the swimming feet. When they have acquired eleven segments in the antennx, the rami of the swinnming feet have become three-jointed, $i . c$. , have reached their adult condition.

The Figs. I, 5, and 3. Plate III., show, furthermore, that all the characteristics common to the variety, the short second segment of the antemnule, the square basal segment of the fifth foot and the inner fringe of hairs on the inner margins of the caudal stylets, are often present in comparatively young forms.

C. Signatus, var. annulicornis (also known as C. albidus JuRINE), Plate IV., is likewise very abundant at certain seasons in the Long Island waters. It has been found in the greatest numbers in cool, spring-fed pools. In general appearance, in color and in the proportions of the body, ammulicomis closely resembles coronatus, which it sometimes accompanies: or it may be found with widely different species. The characteristics by which anmulicomis can be identified are first, a long second segment in the antennule; second, a relatively long basal segment in the fifth foot; third, the absence of lairs on the inner margins of the caudal stylets: and fourth, the characteristic armature of the imner marein of the distal segment of the imner ramus of the fourth swimming foot. In coronatus this position is occupied by two setre. In anmulicomis the more distal seta is greatly reduced or is wholly wanting, its site then being marked by a cluster of very short hairs.

The antenne of anmulicornis are characteristically long and in their armature they resemble those of coronatus.

* Byrnes, E. F. "Two Transitional Stages in the Development of Cyclops Signatus, var. Coronatus." Biological Bulletin, vol. x., No. 5, April, 1906. 
The rami of the swimming feet are three-jointed. The armature of the terminal segments is as follows:

\begin{tabular}{|c|c|c|c|c|c|c|c|c|}
\hline 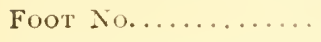 & \multicolumn{2}{|c|}{ I } & \multicolumn{2}{|c|}{ II } & \multicolumn{2}{|c|}{ I I I } & & \\
\hline Ramus, Outer or Inner. . & $\mathrm{O}$ & I & $\mathrm{O}$ & I & $\mathrm{O}$ & I & $\mathrm{O}$ & I \\
\hline Outer Spines ... & 3 & 1 (sa) & 3 & 1 (sa) & 3 & 1 (sa) & 2 & 1 (sa) \\
\hline Apical Spines ... & 1 & 1 & 1 & 1 & 1 & 1 & 1 & 1 \\
\hline Apical Seta .......... & 1 & 1 & 1 & 1 & 1 & 1 & 1 & 1 \\
\hline Inner Setæ . . . . . . . & 3 & 3 & 4 & 3 & 4 & 3 & 4 & $2^{1}$ \\
\hline
\end{tabular}

sa = seta in place of spine. ${ }^{1}$ One seta is minute, or represented by hairs only, the other is normal.

Jounger Stuges of C. Signatus, var. Annulicomis.-From two camera ontlines of younger individuals it appears that the antennze of anmulicomis can attain their maximum length in proportion to the length of the body, when they contain but eleven segments. The basal joint of the fifth foot is likewise characteristically long at this period, and the swimming feet slow adult relations, as in coronatus. The inmaturity of the form is indicated, however, by its relatively small size. by uniform size anong the ablominal segments, by the incomplete number of segments in the antennze and by the pale transparent appearance of the chitin.

A still younger anmulicomis shows ten-jointerl antennat correlated witls two-jointed rami, as in the form coronatus. The second joint in the antennule is relatively long, and there are no hairs on the inner surface of the candal stylets. The distal segment of the inner ramus of the fourth swimming foot lacks setie on the immer median surface, althougl there are plainly inclicated two regions where the hairs and setie usually appear in the later stages. I was at first sceptical about the absence of setre in this position, hecause characteristic spines and setre are usually to be found well developed while the forms are still very young. But the most careful searcli failed to give any evidence of broken surfaces, and I believe in this case the setie had never been developed. It secms to me that the constant correlation of the characteristics citerl slows that we are here dealing with a form quite distinct froni $C$. coronutus, for the claracteristics recur in all the stages of the later molts. 
Variations in C. Signatus, var. Amulicomis.-In the fourth swimming feet I have recorded five cases in which "a tiny seta" is present in the distal position on the inner margin of the distal segment of the inner ramus, and four cases in which this position was occupied by "a tiny bunch of hairs." Sometines only two or three hairs are present.

In the outer ramus of the first foot, I have observed an interesting case of variation, similar to the one noted in $C$. ater, where a seta has given place to spiny serrations on its onter margin. The outer apical spine has become modified in this case, so that on its outer side it is clearly a spine; while on its inner side it is as clearly a seta. Such instances show the ease with which a spine and a seta may become interchangeable, and throw doubt on the value of these structures as organs of specific value.

The synonymy of the two forms that $I$ have in this paper designated as $C$. signatus coronatus and $C$. signatus amulicornis is very complicated. Herrick (I895) regarding ammulicomis as synonymous with tenuicornis, recognizes only the varieties coronatus and tcnuicornis. His diagnosis is as follows: He states that the two varieties have similar armature on the swimming feet, but that tenuicomis differs from coronatus in the absence of serrations on the antennal lamella and in the divarication of the ovisacs. Now, as stated above and as shown by a comparison of Figs. 7 and 4 (Plates II. and $I V$.), there is typically a difference in the armature of coronatus and ammulicornis (tenuicornis Herrick). The antennal lamella of annulicomis sometimes bears serrations (Plate IV., Fig. 5) and coronatus sometimes bears its egg masses in a divaricate position, as I have found in attempting to distinguish the two forms by this character. Comsequently Herrick's diagnosis is untenable. Marsh also recognizes the distinctness of the two forms, which he describes under the names $C$. fuscus and $C$. albidus, JURINE: earlier names given to corresponding European species. The form designated C. gyrinus by Forbes is undoubtedly annulicornis.

While all of the forms of the signatus type that have thus far been encountered in Long Island waters have been mequivocally either coronatus or anmulicomis, nevertheless there are wide ranges of variability in the reduced seta on the inner ramus of the fourth foot of ammulicomis and in the hyaline plate of the antennix of 
both varieties - in short in the most important differential characters of the two varieties.

$$
\text { Cyclops Amcricanus, Marsir (Plate V., Figs. I-3). }
$$

Any one who studies the fresh water Cyclops will note that underlying the many diverse forms under which they appear, there are easily recognizable types to which many of them may be referred. One of these types is represented in C. viridis. The viridis type is characterized by a relatively long slender body that tapers gracefully from the cephalo-thorax to the caudal stylets. The antenne contain seventeen segments and reach nearly to the posterior margin of the cephalo-thorax. The caudal stylets bear but two long setre and the fifth foot is two-jointed: the basal segment may vary in breadtl, but it carries a single seta on its outer angle. The distal segment may likewise vary somewhat in length and breadth, but it carries an apical seta and a spine on its inner angle. Sometimes the spine is well developed but often it is very diminutive. The striking features of the type are illustrated in a general way by Fig. I and Fig. 3 of Plate V... C. Americanus, Marsh (C. insectus, Forbes).

C. Americanus is a relatively large Cyclops found in different localities - in sphagnum swamps, in stagnant water and in fresh water lakes. It is one of the most widely distributed forms encountered in the Long Island waters.

The characteristic distinctions by which C. Americamus (Marsm), can be identified among the various members of the viridis type are to be found chiefly in the armature of the swimming feet which agree in every detail with Marsh's description of them (Plate V., Fig. 2; cf. feet of C. parcus, Plate VI., Fig. 3).

\begin{tabular}{|c|c|c|c|c|c|c|c|c|}
\hline Foor $N_{1} \ldots \ldots \ldots \ldots \ldots$ & & & & & & & & \\
\hline Ranus, Outer or Inner.. & 0 & 1 & $\Theta$ & I & ( ) & I & 0 & 1 \\
\hline Outer spincs ......... & 3 & 1 (sil & 3 & 1 (nit & :3 & 1 (sa & 3 & $1(\mathrm{~s}, \mathrm{z})$ \\
\hline Apical spines ......... & $\theta$ & 1 & 1 & 1 & 1 & 1 & 1 & 2 \\
\hline Ipical set.l.......... & 2 & 1 & 1 & 1 & 1 & 1 & 1 & () \\
\hline Inner seta .......... & 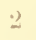 & $\therefore$ & 3 & $\therefore$ & :; & $\therefore$ & 3 & 2 \\
\hline
\end{tabular}




\section{Cyclops Parcus, Herrick (Plate VI.).}

C. parcus, Herrick (Plate VI.. Figs. I and 2), is especially abundant in the collections made in the early spring on Lung Island, and the adult is often accompanied by the later transitional stages of the young.

The form closely resembles $C$. Amcricanus, Marsh. As in the case of the latter species, the thoracic segments appear when slightly pressed to be loosely articulated.

The antenne contain seventeen segments and reach about to the posterior margin of the cephalo-thorax. The armature of the segments is very constant, the typical number of hairs being as follows: $8,4,2,6,4,2,2,1,1,0,1,2,0,1,2,3,7$.

The caudal stylets are relatively long and slender, and bear two long seta, the median seta exceeding the outer one in length. The remaining hairs are short and inconspicuous. They may become slightly setose or remain unchanged.

The armature of the swimming feet of the adults is as follows:

\begin{tabular}{|c|c|c|c|c|c|c|c|c|}
\hline \multirow{2}{*}{$\frac{\text { Foot No........... }}{\text { Ramus, Outer or Inner. }}$} & \multicolumn{2}{|c|}{ I } & \multicolumn{2}{|c|}{ II } & \multicolumn{2}{|c|}{ I I I } & \multicolumn{2}{|c|}{ IV } \\
\hline & $\mathrm{O}$ & I & $\mathrm{O}$ & I & $\mathrm{O}$ & I & $\mathrm{O}$ & I \\
\hline Outer Spines & $2^{2}$ & $1^{1}$ & 2 & 14 & 2 & $1^{1}$ & 2 & 1 : \\
\hline Apical spines. & 0 & 1 & 1 & 1 & 1 & 1 & 1 & 2 \\
\hline Apical Setæ..... & 2 & 1 & 1 & 1 & 1 & 1 & 1 & 0 \\
\hline Inner Setæ ........... & 2 & 3 & 3 & 3 & 3 & 3 & 3 & 2 \\
\hline
\end{tabular}

${ }^{1}$ seta. ${ }^{2}$ weak.

The rudimentary fifth foot of $C$. parcus has a basal segment wider than long and bears a single seta. The distal segment is longer than wide and carries a single seta and a short spine of variable size (Plate VI., Figs. 4, 7). The receptaculum seminis of parcus resembles that of C. brcrispinosus (Plate VI., Fig. S, and Plate VII., Fig. 4).

During levelopment the number of segments in the rami of the swimming feet increases in correlation with that of the antenna. For when the antennxe have nine or ten joints, the rami have two segments, but when the antennx acquire eleven joints the rami 
have three. The three segments are deriverl from two by a transverse division of the distal one, as Fig. 2, Plate XI., plainly shows. The same figure shows that the armature is completeall setie and spines being fully formed- before the segmentation of the ramus begins. At the stage of Fig. 2 the armature is as follows:

\begin{tabular}{|c|c|c|c|c|c|c|c|c|}
\hline \multirow{2}{*}{$\underline{\text { Foot Nr........... }}$} & \multicolumn{2}{|c|}{ I } & \multicolumn{2}{|c|}{ II } & \multicolumn{2}{|c|}{ II I } & \multicolumn{2}{|c|}{15} \\
\hline & $\dot{0}$ & 1 & $\mathrm{O}$ & 1 & $O$ & I & $\mathrm{O}$ & I \\
\hline ()uter spines ... & $: 3$ & $1^{1}$ & ;3 & 11 & ; & $1^{1}$ & 3 & $1^{1}$ \\
\hline Apical Sipines & 0 & 1 & 1 & 1 & 1 & 1 & 1 & 2 \\
\hline Apical Setx..... & 2 & 1 & 1 & 1 & 1 & 1 & 1 & 0 \\
\hline Inner Seta .... & 3 & 5 & 4 & 5 & 4 & 5 & 4 & 4 \\
\hline
\end{tabular}

seta.

Inspection of this armature will show that when the segmentation of the ramus is complete it will have reached its adult condition. The proportions may change mmewhat as the distal segment completes its separation, but the armature remains the same.

Although repeated search has been made for the transitional forms they have very rarely been seen.

A comparison of $C$. Amcricanus and $C$. parcus shows such a very striking agreement between the two forms in many respects as to suggest the probability of a very close relationship. This suggestion is further strengthened by the recasional finding of an adult Cyçops ummistakably C. Amoricanus, M.ıksu, in which most of the swimming fect agree with $C$. Americants in having three cuter spines on the terminal segments of the rami, while others are in the condition characteristic of $C$. parcus, Herrick: $i$. $e$., having lut ta'o outer spines on the terminal segments of the rami. These forms are rather rare, as might be expected, but they serve to suggest that the two achult forms that live side by side in the same localities are differing forms of the same species. The suggested relation of $C$. parcus and $C$. Americams is not based wholly on the variations that occur in the armature of the rami, but partly on analogy with a sinilar case in C. broispinosus, where heterogeny has been definitely determined by experiments in the 
rearing of young from two forms that are found side by side, and that differ from one another precisely as $C$. parcus differs from C. Americanus, Marsir.

In companies of Cyclops of the viridis type, C. Americanus may predominate and only a few forms of $C$. parcus may be present, or $C$. parcus may predominate. Or, as is frequently the case, one of the heterogenous forms may be wholly absent. That heterogeny and polymorphism occur among the Cyclops is well known and fully stated by authors, but in none of the works to which I have had access have any of such forms been either figured or described.

The first Cyclops of the viridis type described in America was C. inscctis, in I882, by Dr. Forbes; later in the same year Herrick described $C$. parcus which seems to have agreed very closely with C. inscctus. C. Ancricanus, Marsh, described in $\mathrm{I} 892$, also resembles $C$. insectus and may be regarded as a synonym for $C$. insectus, according to Forbes.

The close agreement between $C$. parcus and $C$. Amcricamus in their resemblance to the form Dr. Forbes described as $C$. insectus is, it seems to me, explained by the probability that they are heterogenous forms of the same species.

\section{Cyclops Brezispinosus, HerRIck (Plate VII.).}

General Description.-Cyclops brcvispinosus is an inhabitant of stagnant pools. It is a well defined Cyclops closely resembling C. Americanus, MArsil, and C. parcus in its larger outlines. Compare Plates V., VI. and VII. It differs, however, in some details from both of these forms and the differences are relatively constant. The fifth foot is usually broader in proportion to its length than in either parcus or Hmericanus. The caudal stylets are not quite so long, and the armature of the swimming feet is characteristic and constant in its production of spines in definite places instearl of setre.

The armature of the terminal segments of the swimming fect is as follows: 
Armature of adult C. brevispinosus.

\begin{tabular}{|c|c|c|c|c|c|c|c|c|}
\hline Foot Nin. & & & & & & & & \\
\hline Ramus, inter or Inner. . & 0 & I & () & I & () & I & () & i \\
\hline Outer spines & 3 & $1^{1}$ & 3 & $1^{1}$ & 3 & 1 & 3 & 1 \\
\hline Apical spines ... . . . . & () & 1 & $\vdots$ & 1 & 1 & 2 & 2 & 2 \\
\hline Ipical Sietie......... & 2 & 1 & 1 & 1 & 1 & (1) & 1) & 11 \\
\hline Inner setre .......... & 2 & 3 & 3 & 3 & $\ddot{3}$ & 3 & 3 & 2 \\
\hline
\end{tabular}

The fourth foot of an adult ( . breispinosus (Fig. 2, Plate III.), sometimes bears one spine and one seta on the apex of the onter ranuss in place of two spines. The fiftl fout is shown in Fig. 3. Plate VII. This species ayrees with $C$. parcus in the form of the receptaculum seminis, and als, in the labrum which carries nine small teeth between two tooth-like projections of the nuter angles, making a total of eleven teeth.

Herrick clearly recognized the difference between C. parcus and C. bra ispinosus. Forbes also in discussing the members of the iridis group recognized the stable characteristic of brezispinosus and concluded that "Brorispinosus should be considered a good variety." i. e., of C. iridis.

Heterogenous* Form of $C$. Breitspinosus.- Sirle by sile with C. parcus, C. Americanus, MARSH, and C. bremispinosus, is frequently found a cyclops of very sinilar appearance. It is sexually mature and agrees with $C$. parcus in having two outcr spines on the terminal segments of the onter rami of the swimming feet but it differs from C. parcus in the constant occurrence of a well formed spinc on the outer margin of the inner ramus of the fourth s rimming fuot, where there is a seto in c . parcus. The sogments of the onter ramus of the fourth foot of this Crelups are shown i1 Fis. 7 . I'late \'II.

The entire armature of this Cyclops in the "parcus stage" is as follows :

"The term heteroseny is used here to denote the existence of two adult forms which represent successive gonerations, both of which are sexually. mature, but morphologically unlike. 
Armature Formula of C. brezispinosus "parcus-stage."

\begin{tabular}{|c|c|c|c|c|c|c|c|c|}
\hline \multirow{2}{*}{$\frac{\text { Foot No. ............ }}{\text { Ramus, Outer or Inner. }}$} & \multicolumn{2}{|c|}{ I } & \multicolumn{2}{|c|}{ I I } & \multicolumn{2}{|c|}{ III } & \multicolumn{2}{|c|}{ IV } \\
\hline & $\mathrm{O}$ & I & 0 & I & 0 & I & ) & I \\
\hline Outer Sipines. & 2 & $1^{1}$ & 2 & $1^{1}$ & 2 & 1 & 2 & 1 \\
\hline Apical spines.... & 0 & 1 & 1 & 1 & 1 & 2 & 2 & 2 \\
\hline Ipical Setie. ..... & 2 & 1 & 1 & 1 & 1 & 0 & () & 0 \\
\hline Inner Setæ. ..... & 2 & 3 & 3 & 3 & 3 & 3 & 3 & 2 \\
\hline
\end{tabular}

$1_{\text {seta. }}$

The fifth foot is shown in Fig. 9, Plate VII. The labrum and receptaculum agree with corresponding organs of $C$. brevispinosus.

For a long time I sought to link this Cyclops with $C$. parcus because of the general resemblance, hut more careful study showed the distinctness of the two forms. Some light was thrown on its true relationship, by finding, occasionally, a transitional stage, in which the adult conditions were not fully reached. For example, two cases of $C$. brevispinosus occurred in which the fourth swimming feet were in the "parcus-condition," $i$. c., having tw'o outer spines on the distal segment of the outer ramus, while the remaining feet were thoroughly typical of $C$. brerispinosus, $i$. e., having three outer spines on the distal segment of the outer ramus. The armature was as follows:

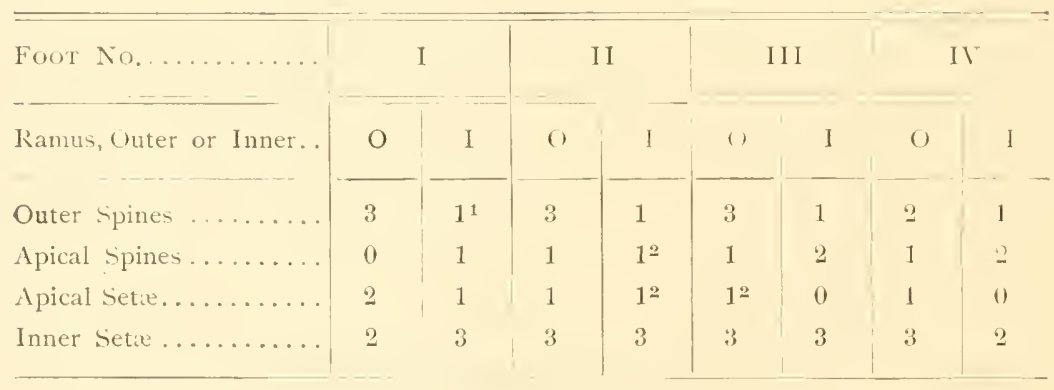

${ }^{1}$ seta. ${ }^{2}$ setose spine.

The variation is seen in the fourth swimming foot where two outer spines appear in the place of the usual three outer spines of C. brcvispinosus. In one case, both right and left rami were alike 
in having the rediced number of spines: in the other case the variation occurred only on one side of the body.

As the fourth feet develop more slowly than the more anterior ones, in accordance with the method of development of appendages in the crustacea generally, it seemed not improbable that the forms with the three outer spines on the terminal segments of the rami might represent older forms that had passed through the condition with only two outer spines.

To evidence of relationship taken from variation in the armature of the swimming feet was added that of the succession of the two types in an aquarium kept under comparatively constant conditions for nearly two years.

In February and March of Igot all the individuals taken from this aquarium were without exception Cyclops of the viridis type, having three external spines.

Nine months later I again harl occasion to search the aquarium for these same forms, but failed to find a single one. The only forms present were Cyclops in the "parcus-stage" with two onter spines, although the charactcristic spine of C. brcvispinosus on the outer margin of the inner ramus of the fourth foot, was present.

C. brezispinosus was then reared to determine the relationship of these two forms experimentally. In the summer of 1905 , sterilized aquaria were set up at Cold Spring Harbor and stocked, each with female C. brerispinosus. The conditions under which Cyclops can be reared without introducing sources of error are necessarily ones which influence and limit the food supply and consequently affect growth. All of the water used in these experiments was filtered and the food, consisting of decayed leaves and water plants, was boiled.

These aquaria were examined on the $5^{5}$ th of the following September and a few young forms were found in two different stages. The younger form had the following correlated characteristics: nine segments in the antennæ and two segments in the rami of the swimming feet. The spines of $C$. brevispinosus were very distinct in the fourth foot, inner ramus, even at this early stage. This distal joint, which in this younger stage is the second instead of the third segment, is armed as follows: 
FOURTH FOOT

\begin{tabular}{|c|c|c|}
\hline Outer Ramus & & InNER RAMUS \\
\hline Spines & 3 & Outer Spine (Immature) ... \\
\hline Spine. & 1 & Apical Spines............ \\
\hline Set & 1 & \\
\hline Rete & 4 & Inner Setie... \\
\hline
\end{tabular}

These terminal sections of the rani must break into two in order to form the characteristic three-jointed rami of the adult.

The older form had the following correlated characteristics: Ten segments in the antennx and three segments in the rami of the swimming feet. The distal segment of the older form is armed as follows:

\begin{tabular}{|c|c|c|}
\hline OUter RaMUS & & INNER Ramus \\
\hline Outer Spines & 3 & Outer Spine ............ \\
\hline Apical Spine $\ldots \ldots \ldots \ldots \ldots \ldots$ & 1 & Apical Spines............... 2 \\
\hline Apical Seta .............. & 1 & \\
\hline Inner Setæ ................ & 3 & Inner Setæ ... \\
\hline
\end{tabular}

This is the adult armature of the fourth swimming feet in $C$. brevispinosus, and the experiment shows that the adult condition is reached at an early stage in the life of the individual.

Just what lappens in the transformation from the two-jointed to the three-jointed stage in the formation of spines I lave not been able to follow.

This experiment threw no light on the relation of the individual in the "parcus-stage" to C. brezispinosus, because the appendages of the young were precisely like the parent forms as soon as they reached the three-jointed condition. It showed, lowever, that the characteristic spines of C. brecispinosus form at an early perior, and that if a spine is to be present, it is present as a spine from the beginning.

Again the young were reared from fertile females and the forms were obtained figured in Plate $V$. The anterior feet are more fully developed than the posterior ones, especially the fourth foot which is, as yet, wholly unsegmented.

Slwuld these distal segments of the first and second rami separate into two segments as was seen in C. parcus, Fig. 2, Plate XI. it would result in the formation of a "parcus-stage" having two outer spines on the distal segments, in place of three. I have, however no proof that such a separation occurs without the formation of additional spines. 
It has been repeatedly noticed that the proxinal spine on the terminal joint of the outer ramus of C. brerispinosus is usually. smaller than the more distal ones (Fig. 8. Plate VII.). This smaller size probably means a more recent formation, but I have been unable to find any direct proof of this. I have not seen the origin of this spine.

Failing to obtain prouf of the descent of the "parcus-stage" from C. bresispinosus, fertile females of the "parcus-stage" were isolated and from these individuals were reared $C$. brcvispinosus with the threc outer spincs. All of these young that were observert were males. Whether or not they produce only males 1 am not prepared to say:

This experiment entirely establishes the true relation between the two forms, however, and illustrates a striking case of heterogeny.

Just what relation these two heterogenous forms bear to one another in the line of descent has not been fully determined. But of their close relationship no doubt remains. They are both abundant, similar in appearance and both attain to the later stages of sexual maturity side by side, but maintain a marked difference in armature that might almost seem to indicate a distinct difference in the species of the two forms.

T'uriutions in Cyclops Breispinosus.-A marked variation in C. brcispinosus is scen in certain individuals that show a modification in the armature of the outer ramus of the fourth swimming feet. The usual armature of the inner margin of the outer ramus is three setre (Fig. 2. Plate VII.). In the modified form one or two of these setre become distinct spines, so that the entire armature is as follows:

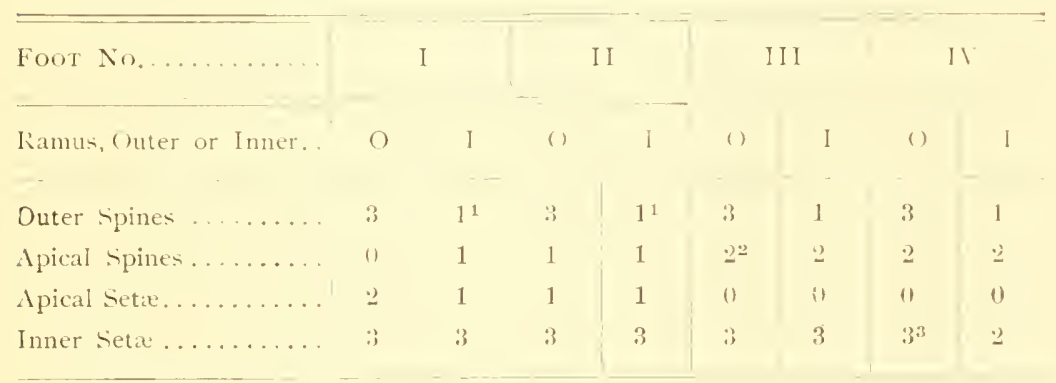

$\mathbf{1}_{\text {seta. }}$ zunequal. $\quad 32$ spines +1 seta. 
A comparison of this armature with the typical armature of C. brearininosus shows that the modified form has a marked tendency toward the formation of spines.

A table of armatures setting forth the variations in a series of eighteen individuals shows sewen individuals with one spine and one seta on the apical border of the inner ramus of the third foot, and eleven with ta'o large spines. Of these eleven, three had apical spines on all the rami of the third and fourth feet. This shows a tendency toward a correlated variation in armature, although I have detected no correlated variation in other structures. Should this tendency toward the production of spines become fixed, it would lead eventually to the formation of a new variety.

\section{Cl'clops Ingens? (Plate T'III.).}

I somewhat rare Cyclops of large size and characteristic appearance is occasionally found in connection with $C$. brevispinosus. This form is of the ziridis type. In color it is pale yellow (mooncolor), with greyish swimmerettes and greyish markings on the borders of the segments. I am inclined to think this may be $C$. ingens of HERRICK, a form he describes as "the largest yet encommtered in America; it is simply an exaggeration of the last," $i . e$., Cyclops Americanus, MArsh, "there being no obvious distinctions except in size."

I have found only the females of this form. They agree with C. brevispinosus rather than with C. Americanus, MARsH, for they have the spine that is so characteristic of this species in place of the seta of the species described by Professor Marsh. Moreover, they present the two heterngenous forms that are common to $C$. braispinosus. The resemblance between this larger Cyclops and breispinosus is further increased by finding the same pale yellow color in some of the individuals of the latter species. It may, therefore, be doubted whether these larger individuals represent even a distinct variety, so similar are they to brovispinosus in both of its pliases.

All of these larger Ciclops were taken from larger bodies of water, and their larger size may be the result of their enviromment, such as a more abundant supply of nxygen and of food. 
Cyclops Virido-Signatus (Plate IX.). New Species.

This Cyclops, figured on Plate IX., seems to be an unnaned form peculiar to its locality. It was taken from a sphagnum swamp at Jamaica, Long Island, and was so abundant in that locality that dolult males and females were taken in a single collection, together with the later stages of the young. Although frequent collections had been made from this locality in previous years the form had not been previously encountered there. Accompanying it were several Cyclops of the viridis type, especially C. Americanus, MARsH, which it resenbles in color and in general appearance. The ontline of the body of this form is shown in Fig. I, Plate IX., in an adult female in which the antenna contain only twelve segments. There was no sign of further segmentation in the segments of these antenna, although the hairs on the longer segments occupied such positions that. should the segments break up into smaller ones at the level of the hairs, seventeen segments conld arise with an armature corresponding very closely to the nsual armature of a typical seventeen-jointed antenna.

The labrum carries only eight large teeth on a narrow plate. The abdomen contains five segnents in the male and four in the female. The caudal stylets are profusely corered with hairs over the entire surface. The stylets carry but two long sete as in the riridis type, but even the short hairs are strongly setose. The armature of the swimming feet agrees with that of $C$. parcus, as follows :

\begin{tabular}{|c|c|c|c|c|c|c|c|c|}
\hline \multirow{2}{*}{$\frac{\text { Fow No............ }}{\text { Ramus, Outer or Inner. }}$} & \multicolumn{2}{|c|}{ I } & \multicolumn{2}{|c|}{ I I } & \multicolumn{2}{|c|}{ III } & \multicolumn{2}{|c|}{$\mathrm{II}^{-}$} \\
\hline & O & I & (1) & I & $\omega$ & 1 & 0 & I \\
\hline Outer spines & 2 & $1^{1}$ & 2 & $1^{i}$ & 2 & $I^{1}$ & 2 & $1^{1}$ \\
\hline Ipical spines ........ & 0 & 1 & 1 & 1 & 1 & 1 & 1 & 2 \\
\hline Ipical Setie... & 2 & 1 & 1 & 1 & 1 & 1 & 1 & 1) \\
\hline Inner Setie.. & 2 & 3 & 3 & 3 & 3 & 3 & 3 & 2 \\
\hline
\end{tabular}

1 seta

The fifth feet are two-jointed. having a basal segnent loroater than long and carrying an outer seta, and an almost square distal segment having a median plimose seta and two very slint blunt spines, 
one on either side of the seta. The foot strongly suggests the fifth foot of $C$. signatus, but the spines are much shorter. Among the individuals of this group there was a great uniformity in the armature of the fifth foot. Because of the combined characteristics of the two types, riridis and signatus, seen in this Cyclops, I have designated it $C$. sirido-signatus.

The receptaculum seminis seems to consist of three broadly oral masses tapering slightly posteriorly.

In the male the characteristics of the female are repeated in the armature of the swimming feet, in the fifth feet and in the stylets. The first abdominal segment is almost circular in outline when seen from above, so wide is it. In the young of the form, the posterior margins of the abdominal segments are all very coarsely serrated as is also the posterior margin of the fifth thoracic segment.

In the young forms there is the usual correlation between the ten-jointed antenne and the two-jointed condition of the rami as has been noted for other Cyclops.

\section{Cyclops Pulchcllus (Herrici). (Plate X.)}

The form here identified as C. pulchillus (IIERRICK) is a comparatively small Cyclops of marked transparency even when loaded with ova, which it produces in great abundance. The color is a delicate blue. This species was taken from a sphagnum swamp together with C. zirido-signatus, figured on Plate IX.

The cephalo-thorax is noticeably pointed in front and is broadest near its middle region. The abdomen is long and slender with comparatively elongated caudal stylets that carry two long plumose setre. The antennie reach about to the third thoracic segment and contain seventeen segments. The basal segment is very long and narrow and the last three segments grow progressively longer, as Herrick pointed out.

The receptaculum seminis appeared very sharply outlined in the adult females (Fig. 3, Plate X.). It consists of a wide low arch directed anteriorly and of a narrower and deeper arch directed posteriorly. In the middle region the sac is constricted. The labrum is edged with thirteen very small teeth. The swimming fcet are armed as follows: 


\begin{tabular}{|c|c|c|c|c|c|c|c|c|}
\hline 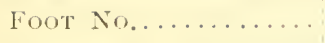 & & & & & & & & \\
\hline Ramus, Uuter or lnner. & 0 & I & () & I & () & I & () & 1 \\
\hline Outer Spincs ......... & 2 & $1^{1}$ & 2 & $1^{1}$ & 2 & $1^{1}$ & 2 & $1^{1}$ \\
\hline Apical spines... & 0 & 1 & 1 & 1 & 1 & 1 & 1 & 2 \\
\hline Ipical Setir........... & 2 & 1 & 1 & 1 & 1 & 1 & 1 & 0 \\
\hline Inner Sietix ... & 2 & 3 & 3 & 3 & 3 & 3 & 3 & 2 \\
\hline
\end{tabular}

This armature agrees with that of $C$. parcus. The rudimentary fiftl foot is two-jointed. The basal joint is very short and iarrow and bears an outer seta, often without barbs. The distal segment is long and narrow and bears two terminal hairs resembling that on the basal segment in general character and in length (Fig 3 . Plate X.).

\section{Cyclops Bicuspidatus. Forbes (Plate X.).}

This species was found at (ypress Hills, Long Island, and was collected with C. Amoricamus, MARsin ( $C$. inscctus, Forres) and C. parcus (Herkick).

It belongs to the same general type as $C$. pulchellus, lut is larger and differs somewhat in the shape of the cephalo-thorax. in the length of the antenne, in the character of the fifth foot and in the outline of the receptaculum seminis. In the armature of the swimming feet, the species also agrees with C. parcus.

In the later stages of the arlult condition there are seventeen segments in the antenna but there may be only thirteen segments, even when the form is sexually mature as shown in Fig. 5, Plate X.

The segments of the fiftl foot agree very closely with corresponding segments in C. pulchcllus but the armature on the inner angle of the distal segment differs in the presence of a strongly serrated spine of abont lalf the length of the adjacent seta.

The receptaculum seminis has a low wide arch directed anteriorly. It suggests the receptaculum of $C$. pulchcllus but the ontlines drawn differ, owing partly to the fact that it is full in the specinen drawn of C. bicuspidatus, and partly empty in the specimen of C. put- 
chellus. In C. bicuspidutus the caudal stylets are relatively shorter and more delicate than in the other nembers of the riridis type.

Forbes records having found intermediate forms of Cyclops that bridge the gap between $C$. bicuspidatus and $C$. pulchcllus, variety Navus (Herrick). He also states that there is no need of considering $C$. thomasi even as a variety. Forbes finds $C$. bicuspidatus very widely distributed in America and subject to a very wide range of rariation: It is a common pelagic form but is found also in ponds.

Life in ponds, according to this anthor, tends toward the development of more robust forms: while the more slender forms are found in the deeper waters of lakes. In the Long Island collections, I have encountered this form in a very limited locality in a very shallow pool abundantly filled with water plants. Collections have usually been made in this locality in the spring. when it is characteristic of the form to become sexually mature while the antennx contain but thirteen segments (Fig. 5, Plate X.), although ultimately the antennæe acquire seventeen segments (Fig. 4. Plate X.).

\section{Cyclops Modestus (I'late XI., Figs. + and 5).}

This is a comparatively small species with very characteristic color markings. The whole body is suffused with a pinkish tint while the swimming feet are strongly colored a deep purplish red. This color belongs rather to the chitin than to the protoplasm and persists for many months in specimens preserved in glycerine. C. modestus was found at Cold Spring Harbor in sluallow spring fed ponds. It was especially abundant in collections made from the bottom in the summer of I905. though collections made from this same locality in previous years contained no Cyclops of this species.

In general morpholog! the Cold Spring Harbor form agrees with Professor Marsh's description of C. modestus, found in the region of the Great Lakes, but it differs in some details from Professor Herrick's account of C. modestus. The fifth foot is z'ery distinctly three-jointed not "obscurely" as Herrick observed.

The antennx are characterized by greatly elongated hairs on the first, second, fifth, tenth and thirteenth segments, althongh several of the other segments also produce long hairs.

The armature of the swimming feet is as follows: 


\begin{tabular}{|c|c|c|c|c|c|c|c|c|}
\hline Foor No. . . ....... & & & & & & & & \\
\hline Ramus Outer or Inner.. & 0 & 1 & () & I & () & I & () & I \\
\hline Outer Sipinen & 3 & $1^{1}$ & 3 & $1^{1}$ & 2 & $1^{1}$ & 2 & 11 \\
\hline Apical spines. & 1 & 0 & 1 & 0 & 1 & 1 & $1^{3}$ & 2 \\
\hline Ipical Seta.. & 1 & $3^{2}$ & 1 & 2 & 1 & 1 & 1 & 0 \\
\hline Inner sietio ... & 3 & 2 & 4 & 3 & 4 & 3 & 4 & 2 \\
\hline
\end{tabular}

C. modestus seems to represent a well determined type in which the forms are stable and in which there is but slight variation.

Cyclops Sermulatis. Forbes (I'late XII.).

C. scrrulatus is a small orange colored Cyclops of very wide distribution. It is for the most part an inlubitant of fresh water streams and ponds. I have usually found C. serrulatus in company with $C$. signatus, which is a much larger form and which sometimes preys upon it. It is easily reconnized by its small size, its pronouncerl color and by its quick darting movements. There are two clearly distinguishable forms of $C$. scrmlatus in one of which the ova are dark olive green, both when in the ovaries and when appended to the body. In the other form, the ova are a dark purple. The characteristics of C. scrmlotus, Forises, are all present in the Long Island forms. The only difference from the type is seen in the armature of the swimming feet. The armature is as follows:

\begin{tabular}{|c|c|c|c|c|c|c|c|c|}
\hline \multirow{2}{*}{$\begin{array}{l}\text { Foot No.......... } \\
\text { Ramus, (juter or Imner. }\end{array}$} & \multicolumn{2}{|c|}{ I } & \multicolumn{2}{|c|}{11} & \multicolumn{2}{|c|}{111} & \multicolumn{2}{|c|}{ IV } \\
\hline & () & I & () & I & () & I & (1) & 1 \\
\hline Outer spines ........ & :3 & $1^{1}$ & 3 & 11 & :3 & 11 & 2 & $1^{1}$ \\
\hline Apical spines......... & 12 & I & 1 & 1 & 1 & 1 & 1 & 2 \\
\hline Apical seta.......... & 1 & 1 & 1 & 1 & 1 & 1 & 1 & 11 \\
\hline Inner lieti .......... & 3 & 3 & 1 & 3 & 1 & 3 & 1 & 2 \\
\hline
\end{tabular}


Herrick records an outer spine instead of a seta on the innerramus in the third and fourth feet. As all the forms I have examined agree in the armature, this variation is probably more or less constant in the forms from the two localities, $i$. $e$, west and east.

It is very characteristic of $C$. serrulatus that the first pair of swimming feet is disproportionately small in comparison with the corresponding feet of other species. This fact often affords a ready means of immediate recognition.

I attempted to rear the young of $C$. serrulatus to determine the significance of the different colors of the ova in the two types, but I have as yet no light to throw on the relationship of these forms.

\section{Cyclops Fluviatilis, Herrick (Plate XV., Figs. I and 2).}

This species, as found by me on Long Island, is so small as to be easily overlooked. Under the microscope it is, however, recognized with facility by its color markings. The cuticula is yellow and strongly splotched with dull bluish-green patches rather irregularly scattered over the body. Herrick* (1895, p. Ir4) speaks of "a smaller age form which is barely visible to the eye," and of a "larger and more highly colored condition." Only the smaller form has been seen in the Iong Island waters. It is, however, sexually mature as is indicated by the enlarged first segment of the abdomen, by ova within the body and by appended embryos which, though few in number are of relatively large size.

C. flutiatilis was abundant in the collections made in the summer of 1905, at Cold Spring Harbor, though I had not encountered it there previously.

The Cold Spring Harbor form agrees very closely with Herrick's description. The antenne reach about to the abdomen and contain greatly elongated segments, from the seventh to the ninth, as Herrick pointed out.

The swimming feet are likewise armed with very long sete. The armature of the terminal segment of the swimming feet is as follows:

\footnotetext{
* "Copepoda, Cladocera and Ostracoda of Minnesota." Geological and N'atural History Survey of Minnesota. I895.
} 


\begin{tabular}{|c|c|c|c|c|c|c|c|c|}
\hline \multirow{2}{*}{$\frac{\text { Foot No.............. }}{\text { Ramus, Outer or Inner. }}$} & \multicolumn{2}{|c|}{ I } & \multicolumn{2}{|c|}{ II } & \multicolumn{2}{|c|}{ II I } & \multicolumn{2}{|c|}{ IV } \\
\hline & 0 & I & $\mathrm{O}$ & I & $\mathrm{O}$ & I & 0 & I \\
\hline Outer Spines ..... & 3 & $1^{1}$ & 3 & $1^{1}$ & 3 & $1^{1}$ & 2 & $1^{1}$ \\
\hline Apical Spines......... & 0 & 0 & 1 & 1 & 1 & 1 & 1 & 1 \\
\hline Apical Seta.... & 2 & 2 & 1 & 1 & 1 & 1 & 1 & 1 \\
\hline Inner Sete .......... & 3 & 3 & 4 & 3 & $t$ & 3 & 4 & 2 \\
\hline
\end{tabular}

sseta.

In the armature of the second and third swimming feet Herrick records two apical setæe in place of one apical spine and one apical seta. In this form, however, the long spines are so weak that they sometimes suggest setæ, only they are broader. The distinctions between spines and setæe are often not very clearly marked in fluviatilis, but this lack of strong differentiation is not attributable to age, since it is found in sexually mature forms.

"The labrum has about twelve small teeth," according to Herrick. The Long Island form has twelve small teeth between two toothlike projections at the outer angles of the labrum, making a total number of fourteen.

\section{Cyclops Bicolor (Plate XIII.).}

This species was taken but once at Cold Spring Harbor and has not been seen in any of the other collections niade on Long Island. It was found in a fresh water pond cloked with a dense growth of Utricularia.

C. bicolor is a comparatively small Cyclops of rather striking appearance. The thorax and aldomen are of a pale yellow color (moon-color). while the rami of the swimming fect are flushed with a delicate purplish blue.

The antenne reach barely to the posterior edge of the cephalothorax and are provided with several enormously long hairs. They contain each twelve segments.

The complete armature of the terminal segments of the swimming feet is as follows: 


\begin{tabular}{|c|c|c|c|c|c|c|c|c|}
\hline \multirow{2}{*}{$\frac{\text { Foot No............. }}{\text { Ramus, Outer or Inner.. }}$} & \multicolumn{2}{|c|}{ I } & \multicolumn{2}{|c|}{ II } & \multicolumn{2}{|c|}{ III } & \multicolumn{2}{|c|}{$\mathrm{IV}^{\mathrm{T}}$} \\
\hline & 0 & I & 0 & I & O & I & $\mathrm{O}$ & I \\
\hline Outer Spines & 3 & $1^{1}$ & 3 & $1^{1}$ & $: 3$ & 11 & 2 & $1^{1}$ \\
\hline Apical spines... & 0 & 1 & 1 & 1 & 1 & 1 & 1 & 22 \\
\hline Apical Seta..... & 2 & 1 & 1 & 1 & 1 & 1 & 1 & 11 \\
\hline Inner Setie. & 3 & 3 & 1 & 4 & 4 & $t$ & 4 & 3 \\
\hline
\end{tabular}

1 seta. 2 unequal.

Herrick does not give the armature of the first, second, and third feet of the inner ramus, and on the outer margin of the inner ramus of the fourth foot, he records a spine. The fifth foot bears one long hair without barbs or serrations on its apex. It consists of a single cylindrical segment, of which the length is approximately four times the width. The abdomen is rather slender and bears the usual caudal stylets, armed with two long terminal setæ. The median seta is longer than the outer one. At the base of the setre are three short stout hairs without barbs or serrations; a delicate one on the median side of the long setre, and a stouter one on the onter angle of the stylet. The third hair is posterior and small. From the side of the stylet, near its middle region, projects a stout hair, almost at right angles.

The particular Cyclops studied was a female without ova and containing numerous orange colored spheres, characteristic of young individuals; but that the form was sexnally mature is shown by the enlargement of the first abdominal segment as well as by the enlarged receptaculum seminis.

Its antenne were twelve-jointed; rami of the swimning feet, twojointed; fifth foot, one-jointed.

The species C. bicolor is usually placed (c.g., by Marsh) among Cyclops having ten or eleven segments. The occurrence, therefore, of a twelve-jointed antenna shows that considerable variation may occur in this organ. Except in this respect the form from Cold Spring Harbor agrees with Professor Marsh's description.

Herrick* (I895, p. II9) finds the fifth foot consisting of "a fleshy basal segment more or less coalesced with the last thoracic

* "Copepoda, Cladocera and Ostracoda of Minnesota." Geological and Natural History Survey of Minnesota. I895. 
segment and bearing a curved spine externally and a terete terminal segment . . . which has an apical seta, four times its own length." The Coll Spring ILarbor Cyclops of this type gives no evidence whatever of having more than a single segment in its fifth foot. Following the nomenclature of Professor Marsh. however, this form is nevertheless to be regarded as $C$. bicolor in which the fusion alluded to by Herrick is complete, if indeed we are justified in assmining that the fifth fort ever contained nore than one segment. Having but a single specimen, it is not possible to discuss this point profitably, but in the instance cited, the relation of parts is unequivocal.

\section{Cyclops Phaleratus (Plate XIY.).}

C. phaleratus has been found rather widely distributed in the collections made on Long Island, though it has not been found abundant in any one locality. In my experience it frequents shallow fresh water ponds. It can be easily recognized by its plunging movements in the water and by the ease with which it crawls over dry surfaces.

In general apearance $C$. phaleratus is opaque. It is relatively thick in body, the abdonen tapering but slightly belnind the cephalothorax. C. phaleratus is often highly colored: orange tones prevailing over the body excepting the second thoracic segment which is usually quite colorless, although some authors call it blue. The ova within the body are a dull blue.

The antenna contain as a rule eleven segments; in a single instance one individual had ten segments in one of its antenne, but only on one side of the borly. Fig. 3. Flate XIV.. shows the left antenna with ten segments; the right antenna of the same individual is shown in Fig. 4 , with eleven segments. The eleventh segment is evidently formed by the division of the elongated sixth segment at the level of the long hair it carries. This division results in the formation of a small sixth segment and a longer seventh segment in the eleven-jointed antenna. Tlerrick noted that the antenuse were uswally ten-jointed, but were frequently cleven-jointer. It seems probahle that the greater number of sesments is to be regarded as the ultimate condition of the species rather than as a case of variation. The rani of the swimmung fect are three-jointed with a terminal armature as follows: 


\begin{tabular}{|c|c|c|c|c|c|c|c|c|}
\hline \multirow{2}{*}{ Fоoт No,.......... } & \multicolumn{2}{|c|}{ I } & \multicolumn{2}{|c|}{ I I } & \multicolumn{2}{|c|}{ III } & \multicolumn{2}{|c|}{$1 V^{r}$} \\
\hline & $\mathrm{O}$ & I & $\mathrm{O}$ & I & $\mathrm{O}$ & I & $\mathrm{O}$ & I \\
\hline Outer Spines .. & 3 & 1 & 3 & 1 & 3 & 1 & 2 & $1^{1}$ \\
\hline Apical Spines......... & 1 & 0 & 1 & 0 & 1 & 0 & 1 & $2^{2}$ \\
\hline Apical Seta... & 1 & 2 & 1 & 2 & 1 & 2 & 1 & 0 \\
\hline Inner Setre......... & 4 & 2 & 4 & 2 & 4 & 2 & 4 & 2 \\
\hline
\end{tabular}

1seta. 21 large and 1 small.

On all of the segments the outer margins of the rami are very strongly spinous or hairy.

The fifth foot is peculiar; the three characteristic "spines" growing right out of the posterior edge of the fifth thoracic segment. I have been unable to detect any trace of a joint in the fifth foot of C. phaleratus. The foot is outlined in camera drawings in Figs. 6 and 9, Plate XIV. A distinct transverse marking occurs beiow the middle seta in Fig. 9, and this may indicate where a joint has been; but the seta to the left grows directly out of the edge of the fifth thoracic segment as does also the seta to the right.

There is some variation in the spinous processes that occur on the fifth feet, as can be seen by a comparison of Figs. 6 and 9, Plate XIV. This difference might easily be due to a difference in the ages of the two forms represented.

Forbes describes the fifth foot in $C$. phaleratus as consisting of a flange-like projection more lateral than ventral, bearing the characteristic armature. The Long Island form differs but little in the shape of the fifth foot from Forbes' description. but shows a distinct variation in the armature of this organ.

Another variation is in the armature of the caudal stylets. The apical structures in the Cold Spring Harbor form are strongly serrated externally. On the inner surface they produce very small hairs (Fig. 5, Plate XIV.).

The posterior edge of the fifth thoracic segment is strongly serrated ventrally as is likewise the posterior ventral edge of the last abdominal segment. The spines are extremely coarse and project over the candal stylets. There is, in general, in C. phaleratus, a strong tendency toward the production of spines. 
The receptaculum seminis is very characteristic, appearing as two broadly oval masses (Fig. 2, Plate XIV.).

\section{Cyclops Fimbriatus, Fischer (Plate XV.).}

Cyclops fimbriatus has been taken in great numbers in some of the collections made in the Long Island waters, especially in collections made in the carly spring. At other seasons it has been found only sporadically.

The form figured in Plate XV. was found in Jamaica. Iong Island. It agrees so closely with Herrick's description of fimbriatus in his report on the Entomostraca of Minnesota, that little further account need be given of it. The variations noted are slight and unimportant.

The characteristics of $C$. fimbriatus are as follows:

The antennx contain but eight segments: they are short and are characterized by two well developed setæ.

The spines and setre of the swimming feet are without any well defined character, although the sexual maturity of the form implies that it is fully developed. The armature of the terminal segments of the swimming feet is as follows:

\begin{tabular}{|c|c|c|c|c|c|c|c|c|}
\hline \multirow{2}{*}{$\frac{\text { Foot No........... }}{\text { Lamus, Outer or Inner. }}$} & \multicolumn{2}{|c|}{$\mathrm{I}$} & \multicolumn{2}{|c|}{ II } & \multicolumn{2}{|c|}{ I I I } & \multicolumn{2}{|c|}{$\mathrm{IV}^{\circ}$} \\
\hline & 0 & I & 0 & I & 0 & I & $\mathrm{O}$ & I \\
\hline Outer Spines ... & i; & 0 & 3 & $1^{2}$ & 3 & $1^{1}$ & 2 & $1^{1}$ \\
\hline Apical Spines... & 0 & $1^{3}$ & $1: 3$ & 1 & 1 & 1 & 1 & 24 \\
\hline Apical Seta........ & 2 & 0 & 1 & 1 & 1 & 1 & 1 & 0 \\
\hline Inner Set: .......... & 3 & 3 & $t$ & 3 & $t$ & 3 & 4 & 2 \\
\hline
\end{tabular}

$$
{ }^{1} \text { seta. }{ }^{2} \text { seta. }{ }^{3} \text { large. tunequal. }
$$

The inner margins of the swimming feet are strongly serrated and hairy. The fifth foot is nne-jointed and hears a coarse inner spine and two setr. Herrick states that the fifth foot bears three spines.

The most striking variation in $C$. fimbriatus is a tendency toward a reduction in the armature of the inner ramus of the first swimming feet, where in the apical position, for cxample, a single large spine replaced two setx or a spine and a seta which is the typical armature of the organ. 


\section{Summary.}

Distribution.-A survey of the Cyclops from the Long Island waters shows that they agree in general with the forms from the western lakes and indicates a rather wide distribution of these species.

Cyclops appear in swarms in certain localities when conditions are favorable and after a period of activity die out, leaving but few representatives. Because of this, forms which are most abundant at one season may become very scarce at another. It is probable, therefore, that the species or varieties reported as sporadic in a locality, such as C. bicolor, may have a season of activity when they are far more numerous than might be inferred from the finding of a single individual.

Variations in Cyclops.-The differences that occur between the western species of Cyclops and those enconntered in the waters of Long Island, such as the differences in the number of spines and setæ in the armatures of the swimming feet; differences in the proportions of the body, etc., are evidently of a varietal nature.

Although the armatures of stable types are relatively constant, spines and setre are interchangeable as is seen in the occasional substitution of a spine for a seta and in the occurrence of half spines in which one side of a spine becomes very strongly plumose, while on the opposite side are equally developed serrations.

These half spines may evidently occur anywhere, but it is significant that they usually occupy either apical positions or lateral positions which approach the apex, where spines and setre occur side by side. This form of variation has been found in widely different types such as $C$. ater, $C$. signatus and $C$. airidis.

An interesting case of variation occurs in the armature of $C$. signatus annulicornis, where in the fourth pair of swimming feet the distal seta on the inner margin of the inner ramus has suffered a reduction so that it may be present as a long seta more slender than the other setx, or it may appear as a very short slender structure without barbs, or, as is often the case, it may be wholly wanting, its site then being marked by a cluster of very diminutive hairs, as shown in Plate IV., Fig. 4.

An apparent variation in the spines of Cyclops is often due to a retardation of growth in the posterior appendages. Retarded 
growth in the third and fourth feet of $C$. signatus coronatus is shown in a young Cyclops with ten antennal segments and twojointed rami. In this Cyclops the swimming feet have such an armature that should the first and second feet become three-jointed, they would be fully armed as in adults. If, however, the third and fourth feet should become three-jointed, they could not acquire the adult armature without the formation of new hairs which when they first appear are quite short. In such instances the apparent variation in the size of the setre is not real variation in the usual sense of the word, but belongs to an entirely different category of phenomena;- to sequence in the development of organisms that undergo slow metamorphic changes and in which the more posterior structures develop later than corresponding anterior ones. Such instances have been observed in C. signatus, C. Amcricanus Marsh, and in C. brciispinosus. This marked reduction in the size of the lower spine on the terminal segments of the swimming feet has also been observed in C. scrrulatus. It is therefore of general occurrence but is indicative of recent formation rather than of any marked tendency to vary in that particular respect.

In the development of spines and setæ on the swimming feet of Cyclops the more distal structures form first. This explains the absence of the lower seta on the basal segment of Fig. 4, Plate III., where there is no inner seta in a young form having eleven antennal segments. In adults, this basal segment invariably carries a seta. The later development of this seta is also expressed in the adult by its relatively small size when compared with the more distal setre of the same ramus.

Herrick recognized two sub-species of the species Cyclops airidis, Jurine (IS20). The American subspecies he designated $C$. Amcricanus, Marsin, and as varieties under the subspecies, he grouped C. viridis, Cragin (I883); C. parcus, Herrick (I883); C. brevicornis, Herrick (I884); C. Americanus, Marsil (I893), and $C$. viridis, Turner (I892). The occurrence of so many forms belonging to the same type and concerning whose identity there exists such a wide difference of opinion. is in itself evidence of a wide range of variation. Forbes records having found forms which completely bridge the difference between two extremes of a series which have been named as separate species, i. c., C. bicuspidatis and $C$. navus of Herrick. 
Among the Long Island forms a wide range of variation occurs among the members of the viridis type. In C. brevispinosus, for example, the type ranges from the smaller forms of the heterogenous form to the largest representative of the group, $C$. ingens?

The size of Cyclops seems to be greatly influenced by the habitat. Brevispinosus reared in a small aquarium in a dark closet for more than two montlss were much smaller than were adult forms taken directly from pools where the food and air supply were unrestricted. This variation in size has been observed in almost every abundant species even in a state of nature.

The study of variation among the Cyclops is greatly complicated not only by the occurrence of sexual precosity (pædogenesis) and by the occurrence of heterogenous forms in certain groups, but also by retardation of metamorphic changes which have superficially the appearance of variations, but which disappear in later stages of development when all the metamorphic processes inave been completed.

It is significant, however, that the greatest ranges of variability have been found among those forms that inhabit stagnant water where conditions are most variable and where only plastic forms could live permanently by adjusting themselves to their varying conditions of life.

Girls' High School, Brooklyn, N. Y., June, I906. 


\section{Literature Cited.}

JuRine, L. I820. "Histoire des monocles qui se trourent aux environs de Genève."

Siebold, von C. IS39. "Beiträge zur Náturgeschichte der IVirbellosen Thiere.'

BAIRD, IV. I850. "The Natural History of the British Entomostraca." Ray Society.

Claus, C. I863. "Die Frei Lebenden Copepoden."

Brady, G. S. I878-I879. "Monograph of the Free and Semiparasitic Copepoda of the British Islands." Chal. Rept. Zoöl. VIII.

Cragin, F. IV. I8S3. "A Contribution to the History of the Fresh Water Copepoda." Tol. S. Transactions of Kansas Academy of Science.

Brady, G. S. 189i. "A Revision of the British Species of FreshWater Cyclopide and Calanidae."

Canu, Eugene. 1892. "Les Copepodes du Boulonnais-\orphologie, Enbryologie, Taxonomie." Trav. de la Station Zoöl. de Wimerenx, YI. Trav, de l'Institut Zoül, de Lille, etc., Vol. II. Marsir, C. D. IS92. "On the Deep Water Crustacea of Green Lake." Vol. VIII. Trans. Wis. Acad. Science, Arts and Letters.

Marsh, C. D. IS93. "On the Cyclopide and Calanidre of Central Wisconsin." Vol. IX. Trans. Mis. Acad. Science, Arts and Letters.

MArsh, C. D. I895. "On the Cyclopidx and Calanide of Lake St. Clair, Lake Michigan and Certain of the Inland Lakes of Michigan.” Bull. Mich. Fish. Comm.

Herrick, C. L. I895. "Copepoda, Cladocera and Ostracoda of Minnesota." Geological and Natural History Survey of Minnesota. Zoöl. Series II.

Forbes, C. B. IS97. "A Contribution to a Knowledge of Nortl American Fresh IVater Ciclopidx." Illinois State Lab. of Nat. Hist. Bull. $\mathrm{I}^{\top}, 5$.

Byrnes, E. F. "Two Transitional Stages in the Derelopnent of Cycłops Signatus, var. Coronatus." Biological Bulletiu, Vol. X., No. 5, April, igo6. 


\title{
THE FRESH WATER CYCLOPS OF LONG ISLAND.
}

\author{
E. F. BYRNES.
}

\section{LIST OF PLATES.}

\author{
PLATE I. CYCLOPS ATER.
}

Camera Drawings. LeITz.

Fig. I. An adult female, showing the general proportions of the body, the antennæ and the caudal stylets.

Fig. 2. The receptaculum seminis of Fig. 1.

Fig. 3. The rudimentary fifth foot of Fig. I.

Figs, 4,5 , and 6 . Three spines from the swimming feet, showing variation in the form of the spines. Fig. 6 represents the transition of a spine into a scta.

\section{PLATE II. CYCLOPS SIGNATUS (CoRonatus). \\ Camera Drawings. LeItz.}

Fig. I. An outline showing the general proportions of the body in an aduit female as seen from the side.

Fig. 2. The outline of an adult male.

Fig. 3. The antennule of Fig. I, showing the short second segment, which is characteristic of the variety, coronatus.

Fig. 4. The two distal segments of the antenna of Fig. I, showing the icrmation of serrations in the hyaline knife edge on the last segment. These serrations are considered characteristic of the variety.

Fig. 5. The rudimentary fifth foot of Fig. I, with its square basal segment, characteristic of the variety.

Fig. 6. The caudal stylet showing the characteristic hairs on the inner margin.

Fig. 7. The outer and inner rami of the fourth pair of swimming feet.

\section{PLATE III. CYCLOPS SIGNATUS (Coronatus). Young Forms.}

Camera Drawings. Leitz.

Fig. I. A young form showing the general proportions of the body, the antennx and the caudal stylets. The antennæ contain but eleven segments. The almost uniform size of the abdominal segments indicates immaturity. The claracteristics of the variety, coronatus, are indicated in the short second joint of the antennule and in the presence of a fringe of hairs on the inner rargins of the caudal stylets. 
Fig. 2. The right outer ramus of the fourth swimming foot of Fig. I, showing three segments. The three-jointed ramus is almost invariably correlated with the eleven-jointed stage of the antennæ.

Fig. 3. A young form, showing the general proportions of the body when there are ten segments in the antenne. The varietal characteristics, $i$. e., the short second segment of the antennule and the fringe of hairs on the inner margin of the caudal stylets are already present.

Fig. 4. The right outer ramus of the fourth swimning foot of Fig. 3, showing but two segments. The two-jointed ramus is almost invariably correlated with the ten- and nine-jointed stage of the antenna.

Fig. 5. The rudimentary fifth foot of Fig. I, showing the characteristic, short, basal segment of the variety signatus coronatus.

\section{PlATE IV. CYClOPS SigNATUS (Annulicornis).}

Camera Drawings. LEITZ.

Fig. I. An outline of an adult female with seventeen segments in the antenna, showing the ocneral proportions of the body. The stylets are without the inner fringe of hairs. The form is slightly distorted by pressure but shows the general relation of parts.

Fig. 2. The antennule of Fig. I, showing the elongated second segment, characteristic of the variety annulicomis.

Fig. 3. The last two segments of the antennze of Fig. I., showing the lyaline knife edge. The distal half of the edge of the last segment is very finely serrated.

Fig. 4. The rami of the fourth pair of swimming feet of Fig. I, showing the characteristic tuft of hairs in place of a seta on the inner surface of the distal segment of the inner ramus

Fig. 5. The rudimentary fifth foot of Fig. I, showing the elongated basal sigment characteristic of the variety.

Fig. 6. An outline of a young female of the same variety, having but eleven segments in the antemle. Rami three-jointed. The fringe of hairs on the imner surface of the slylets is wanting, as in the older forms of the varicty.

\section{PLATE V. CYCLOPS AMERICANUS. MARSH.}

Camera Drawings. LEITZ.

Fig. I. An adult female drawn from the dorsal view, showing the general proportions of the body. The loose articulation of the thoracic segments appeared to be entirely normal and was not dne to pressure.

Fig. 2. The outer and inner rami of the fourth pair of swimming feet of Fig. I. They show the three characteristic spines on the onter margin of the distal segment of the outer ramits and the characteristic scta on the outer margin of the distal segment of the inner ramus.

Fig. 3. The rudimentary fifth foot of Fig. I. 
CYCLOPS BREVISPINOSUS. HeRRICK. Young Form.

Camera Drawings. Leitz.

Fig. 4. An outline of a young cyclops illustrating the general proportions of the body. Antennæe nine-jointed.

Figs. 5, 6, and 7 . Outlines of the outer rami of the first, second and third swimming feet, when they contain but two segments.

Fig. 8. Outline of the outer and inner rami of the fourth swimming feet. The fourth feet develop more slowly than the more anterior appendages, but the characteristic outer spine on the distal segment of the inner ramus is already present. Both rami are unsegmented.

\section{PLATE VI. CYCLOPS PARCUS. HerRICK.}

\section{Camera Drawings. LEITz.}

Fig. I. The outline of an adult female, showing the general proportions ci the body. The antennx contain seventeen segments. Maturity is indicated by the greatly enlarged first abdominal segment, as well as by the presence of the appended ova.

Fig. 2. The outline of an adult male.

Fig. 3. The fourth pair of swimming feet of a male. Both the inner and outer rami are three-jointed.

Fig. 4. The rudimentary fifth foot of the female shown in Fig. I.

Fig. 5. The side view of an adult female.

Fig. 6. The dorsal view of the abdomen and caudal stylets of Fig. 5.

Fig. 7. The rudimentary fifth foot of Fig. 5, showing a broad flat spine in place of the usual short blunt one.

Fig. 8. The receptaculum seminis of Fig. 5, seen in outline from the ventral view.

\section{PLATE VII. CYCLOPS BREVISPINOSUS. HERRICK.}

\section{Camera Drawings. Leitz.}

Fig. I. An adult female drawn from the dorsal side and illustrating the general proportions of the body.

Fig. 2. The outer and inner rami of the fourth pair of swimming feet of Fig. I, showing the characteristic outer spines on the distal segment of the outer ramus and the single outer spine on the distal segment of the inner ramus.

Fig. 3. The rudimentary fifth foot of Fig. I.

Fig. 4. The reeptaculum seminis of Fig. I.

Fig. 5. A young female brerispinosus, having but eleven segments in the antennæ, and abdominal segments of uniform size.

Fig. 6. The rudimentary fifth foot of Fig. 5.

Fig. 7. The second and third segments of the outer ramus of the fourth swimming foot of C. brevispinosus in the "parcus-stage," showing but two outer spines in place of three. 
Fig. 8. The second and third segments of the outer ramus of the fourth swimming foot of Fig. 5, showing the small proximal spine.

Fig. 9. The rudimentary fifth foot of the "parcus-stage" of C. brevispinosus.

\section{PLATE VIII. CYCLOPS INGENS (?) \\ Camera Drawings. Leitz.}

Fig. I. A typical though greatly enlarged Cyclops of the viridis typc, laving the complete armature of Cyclops brerispinosus.

Fig. 2. Three segments of the outer ranus of the fourth swimming foot of Fig. I, with the three characteristic spines on the outer margin of the distal segment.

Fig. 3. A form resembling Fig. I in size, proportions and color, but differing from it in the armature of the swimming-feet. Fig. 3 contains a parasite.

Fig. 4. Three segments of the outer ramus of the fourth swimming foot of Fig. 3, with two spines on the outer margin of the distal segment. I have designated this form the "parcus-stage" of brevispinosus.

\section{PLATE IX. CYCLOPS VIRIDO-SIGNATUS. New Species.}

Camera Drawings. Leitz.

Fig. I. An adult female, showing the general proportions of the body. The antennæ contain twelve segments and reach barely to the posterior margin of the cephalo--thorax. There is no evidence of further segmentation in the antennx. Maturity is indicated by the great elongation and lateral enlargement of the first abdominal segment. The caudal stylets are profusely hairy. The stylets are armed as in the typical parcus forms.

Fig. 2. An adult male, showing geniculate antennæ.

Fig. 3. A young form having ten antennal segments and two-jointed rami in the swimming feet.

Fig. 4. A lateral view of Fig. 3.

Fig. 5. The rudimentary fifth foot of Fig. I.

Fig. 6. The rudimentary fifth foot of Fig. 3 .

Fig. 7. The labrum of Fig. I, showing eight coarse teeth.

Fig. 8. The receptaculum seminis of Fig. I.

\section{PLATE X. CYCLOPS PULCHELLUS. Herrick.}

Camera Drawings. Leitz.

Fig. I. A mature female, showing the general proportions of the body.

Fig. 2. The fifth foot of Fig. I.

Fig. 3. The receptaculum seminis of Fig. I.

\section{CYCLOPS BICUSPIDATUS. FORBES.}

Fig. 4. An adult female $C$. bicuspidatis having seventeen scgments in the antennæ. 
Fig. 5. A mature Cyclops from Cypress Hills, L. I., showing the general proportions of the body. The antenna contain thirteen segments. The rami are three-jointed with the armature of $C$. parcus. Although the antennæ are immature, the form is sexually developed, as is indicated by the enlarged first abdominal segment and the condition of the receptaculum seminis.

Fig. 6. The rudimentary fifth foot of Fig. 5.

Fig. 7. The receptaculum seminis of Fig. 5.

\section{PLATE XI. CYCLOPS PARCUS. Herrick. Young Form}

\section{Camera Drawings. Leitz.}

Fig. I. The outline of a young Cyclops, showing the general proportions of the body. Immaturity is indicated by the small number of segments in the antennx; by the presence of two segments instead of three in the rami of the swimming feet; and by the uniform size of the abdominal segments.

Fig. 2. The right outer and inner rami of the fourth pair of swimming feet of Fig. I, showing two segments. The distal segment is beginning to break into two, the second and third of the adult condition. The position of the setæ and spines with relation to the adult condition is determined before the segments are actually formed. The seta on the outer margin of the inner ramus of the fourth foot and the two spines on the outer margin of the outer ramus, indicate that the form is C. parcus (Herrick).

Fig. 3. The rudimentary fifth foot of Fig. I.

\section{CYCLOPS MODESTUS.}

Fig. 4. An outline of an adult fenale, showing the general proportions of the body, the antennæ and the caudal stylets.

Fig. 5. The ventral view of the fifth thoracic segment with the rudimentary fifth feet. The fifth feet are clearly three-jointed and the first abdominal segment is greatly elongated.

\section{PLATE XII. CYCLOPS SERRULATUS.}

Camera Drawings. Leitz.

Fig. I. An adult female, showing the general proportions of the body.

Fig. 2. A side view of an adult female, showing the general proportions of the body.

Fig. 3. The first pair of swimming feet of Fig. I. They are disproportionately small.

Fig. 4. The fourth pair of swimming feet of Fig. I, drawn for comparison with Fig. 3.

Fig. 5. The rudimentary fifth foot of Fig. I. 


\section{PLATE XIII. CYCLOPS BICOLOR.}

Camera Drawings. Leitz.

Fig. I. An adult female, showing the general proportions of the body. The figure shows the body slightly twisted, so that the thorax is seen from the side, while the abdomen is seen from a dorsal view.

Fig. 2. The left antenna of Fig. I, showing twelve segments. C. bicolor has usually but eleren segments in the antentix.

Fig. 3. The caudal stylets of Fig. I.

Fig. 4. The fourth pair of swinming feet of Fig. I, showing two-jointed rami.

Fig. 5. The ventral riew of the fifth thoracic segment with the rudimentary fifth fect and the first abdominal segment.

\section{PLATE XIV. CYCLOPS PHALERATUS.}

Camera Drawings. Leitz.

Fig. I. An adult female, showing the general proportions of the body. The antennx show ten and eleven segments.

Fig. 2. The ventral view of the abdomen of Fig. I, showing the receptaculum seminis and the serrated margins of the fifth thoracic and the fourth aldominal segments.

Fig. 3. The left antenna of Fig. I, showing cleren segments present.

Fig. 4. The right antenna of Fig. I, showing but ten segments present.

Fig. 5. The caudal stylet of Fig. I. Tentral view.

Fig. 6. The left rudimentary fifth foot of Fig. I.

Fig. 7. An adult female.

Fig. 8. The caudal stylet of Fig. 7, showing oblique rows of spines. Dorsal view.

Fig. 9. The left rudimentary fifth foot of Fig. 7.

\section{PLATE XV. CYCLOPS FLUVIATILIS.}

\section{Camera Drawings. Leitz.}

Fig. I. An adult female, showing the general proportions of ine body. The antenne contain twelve segments. The first, fourth and ninth segments of the antennæe bear exceptionally long hairs and setx.

Fig. 2. The rudimentary fifth foot of Fig. I.

\section{CYCLOPS FIMBRIATUS.}

\section{Camera Drawings. LeItz.}

Fig. 3. An adult female, showing the proportions of the body. The antennae contain eight segments.

Fig. 4. The left antenna of Fig. 3.

Fig. 5. The caudal stylets of Fig. 3, seen from the rentral view.

Fig. 6. The left antennule of Fig. 3.

Fig. 7. The rudimentary fifth foot of Fig. 3 . 



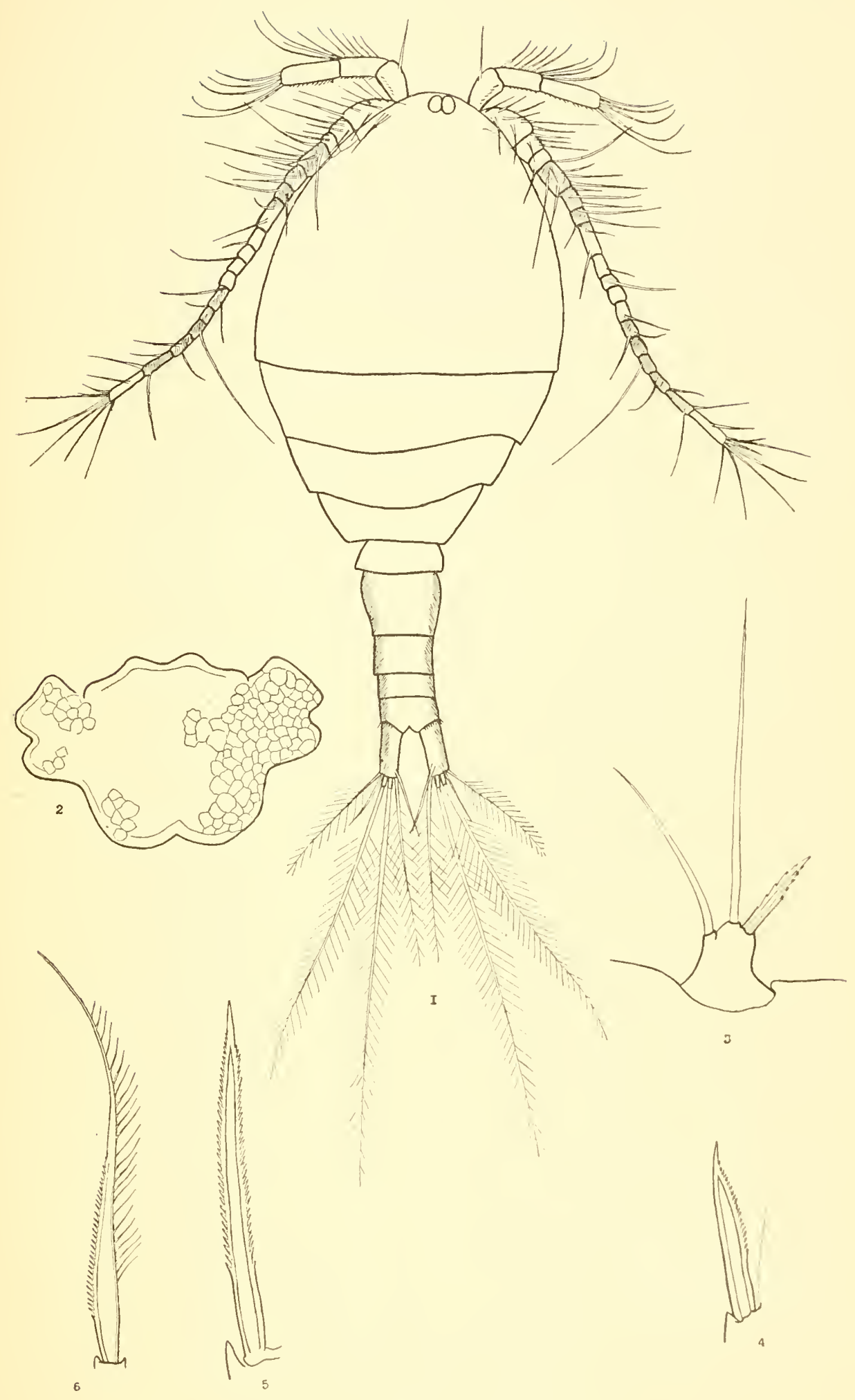





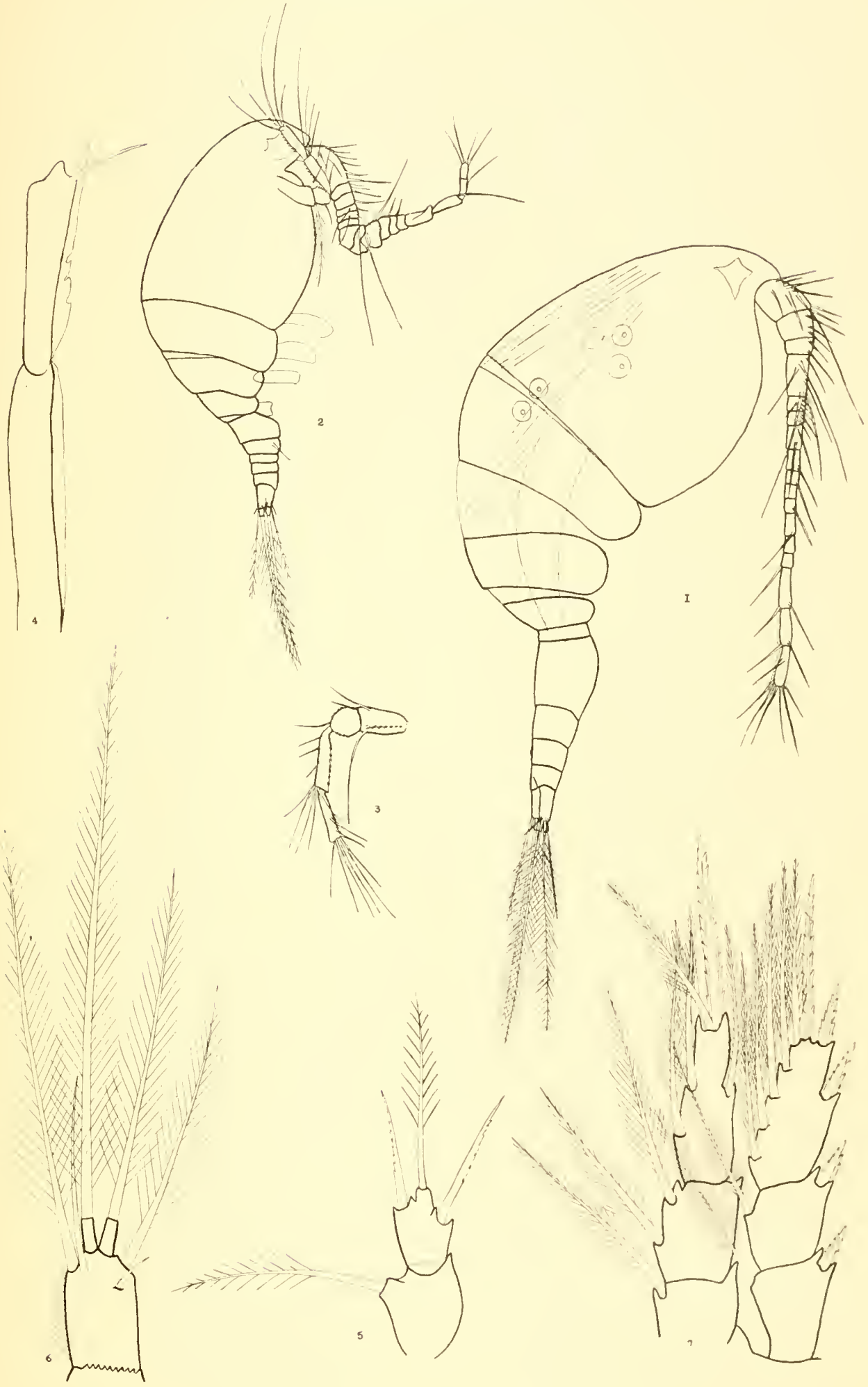



PLATE III CYCLOPS SIGNATUS VAR. CORONATUS, Young Forms E. F. BYRNES

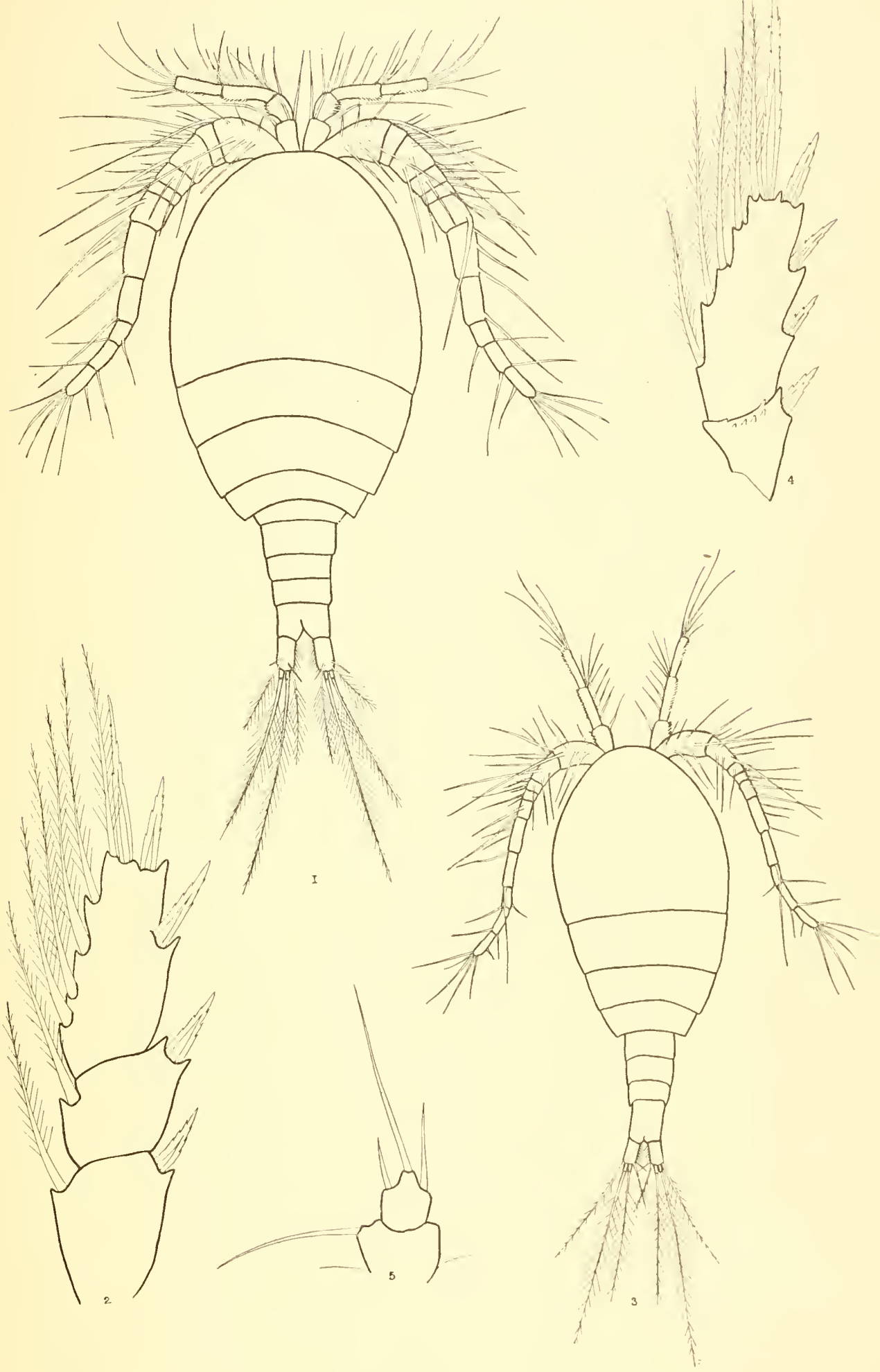




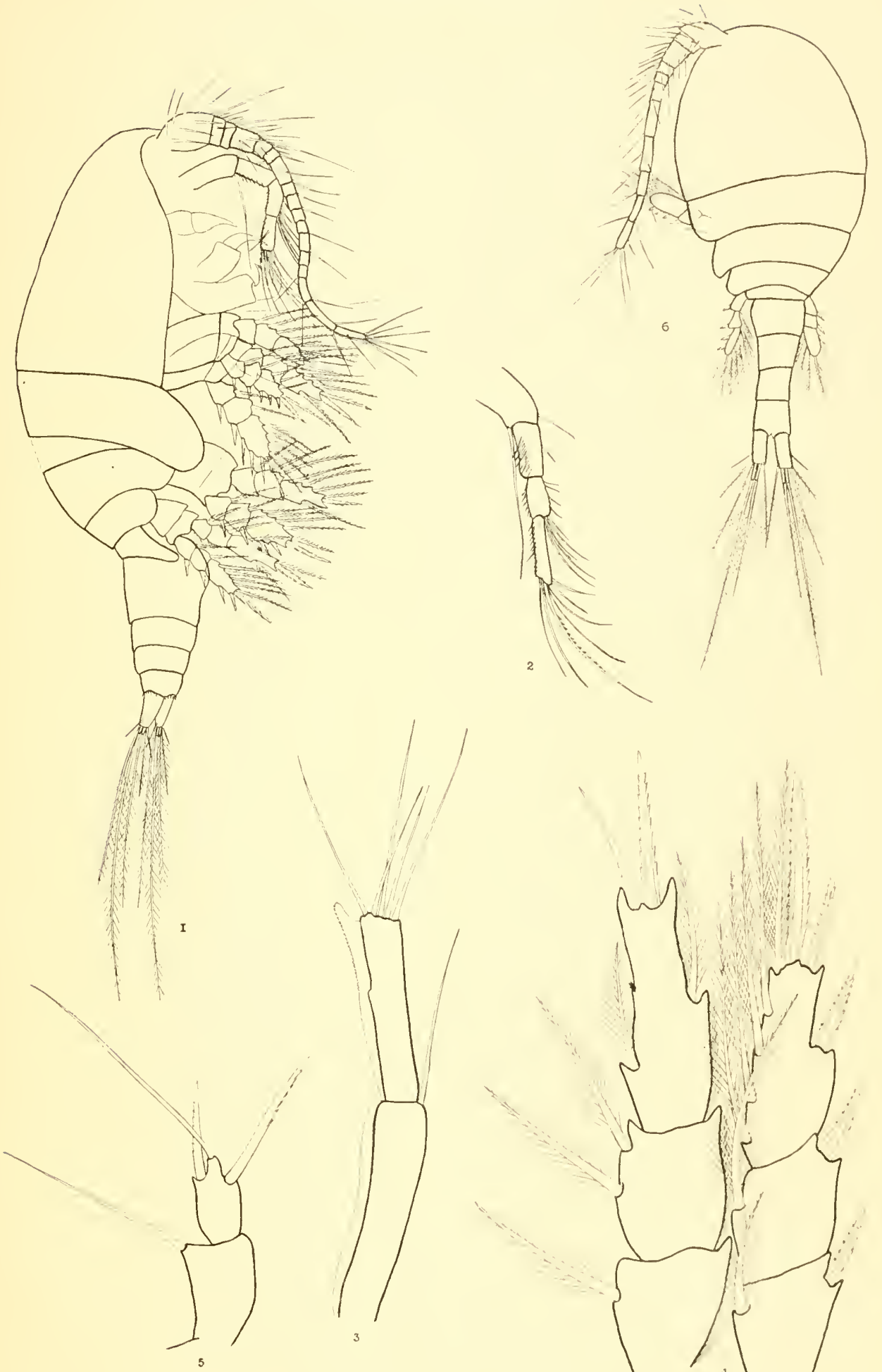


$$
7
$$




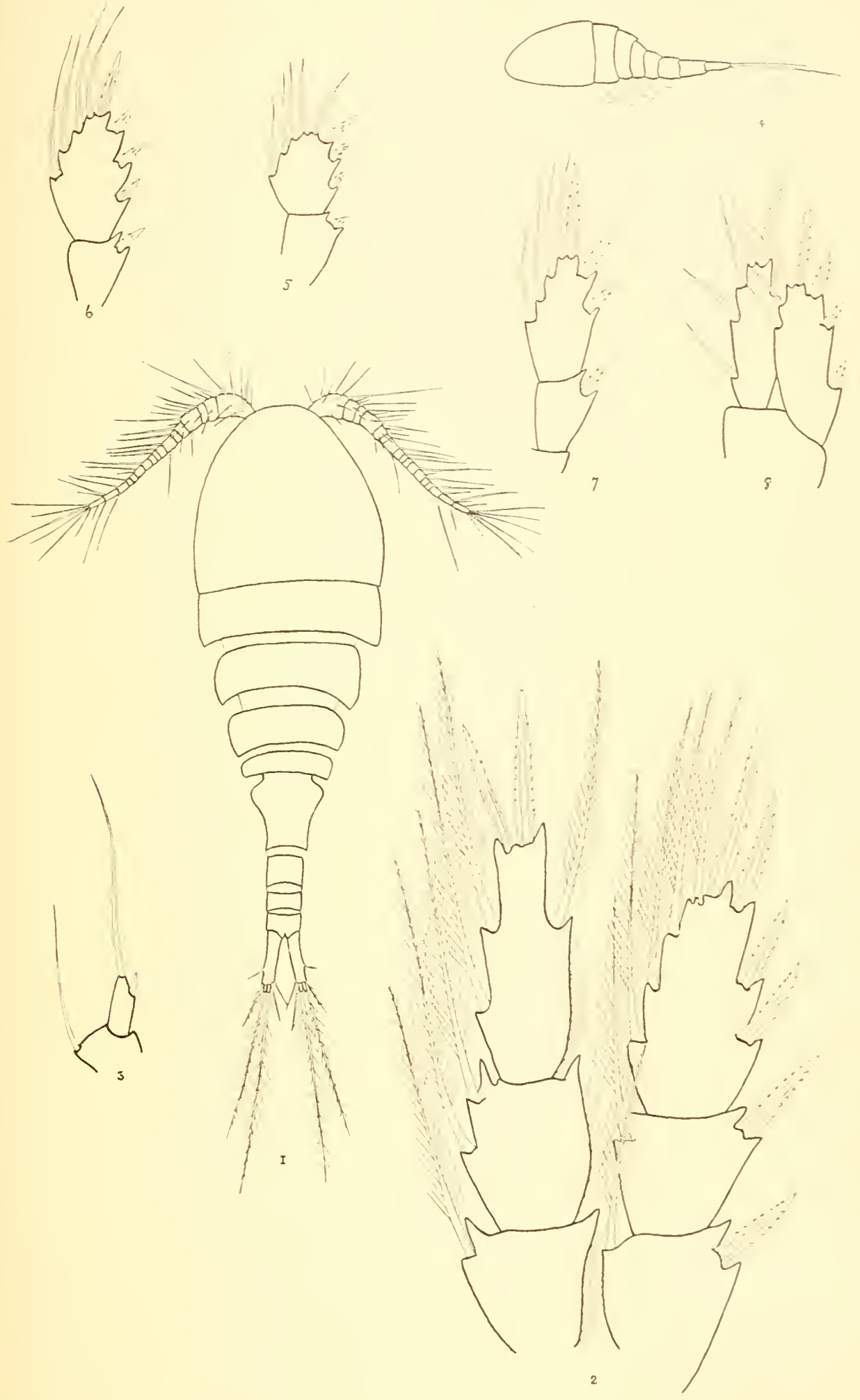





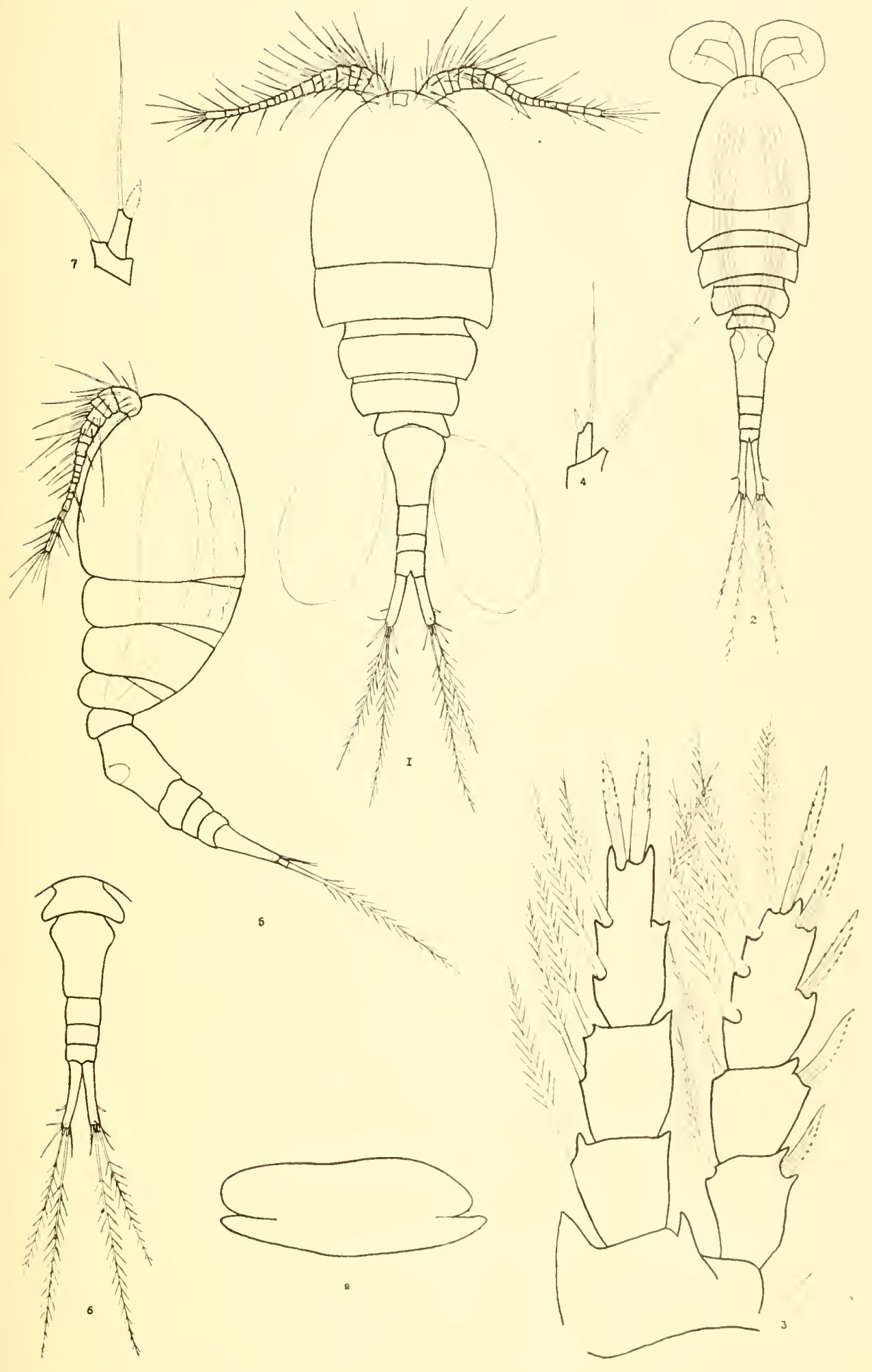




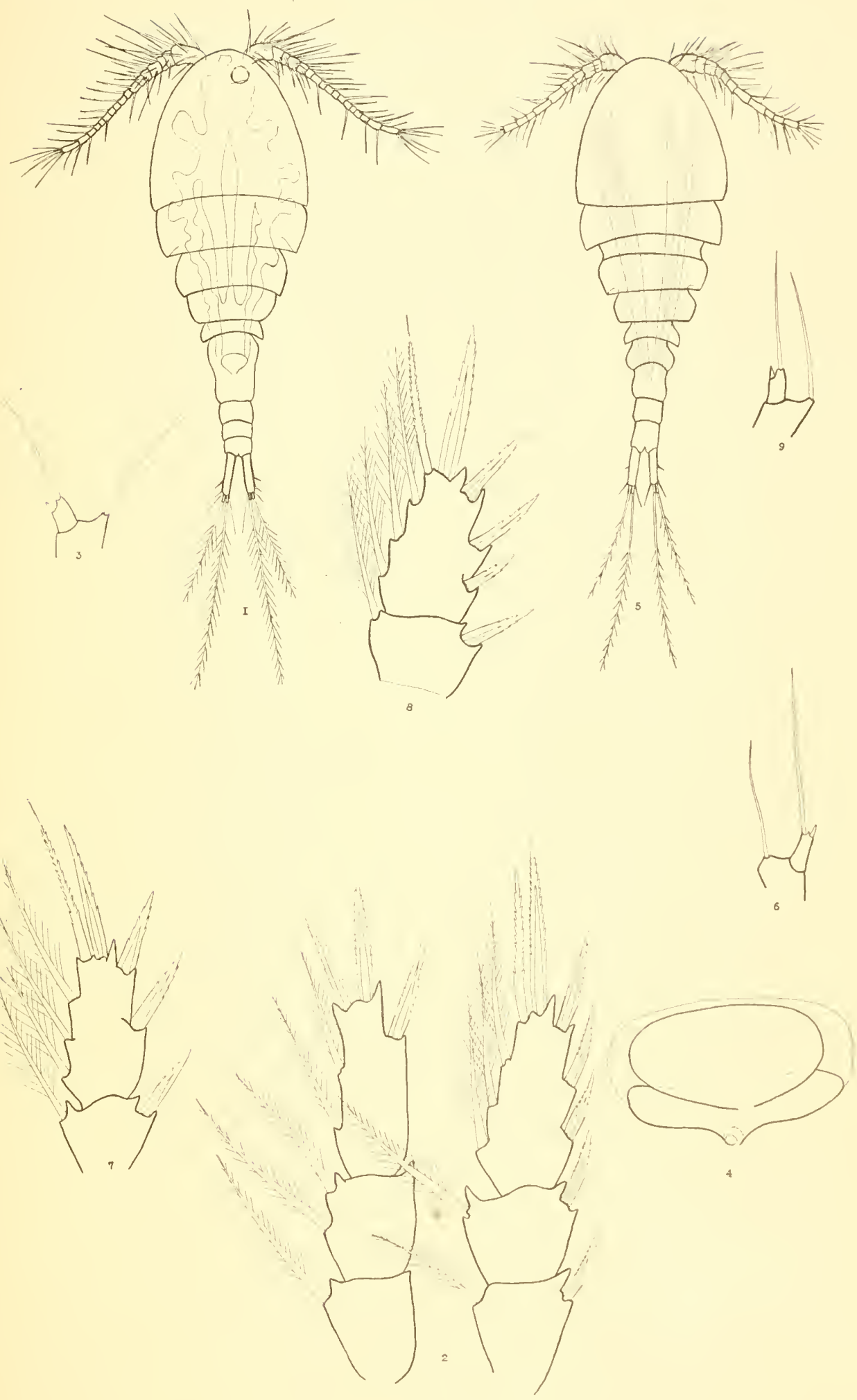
? 

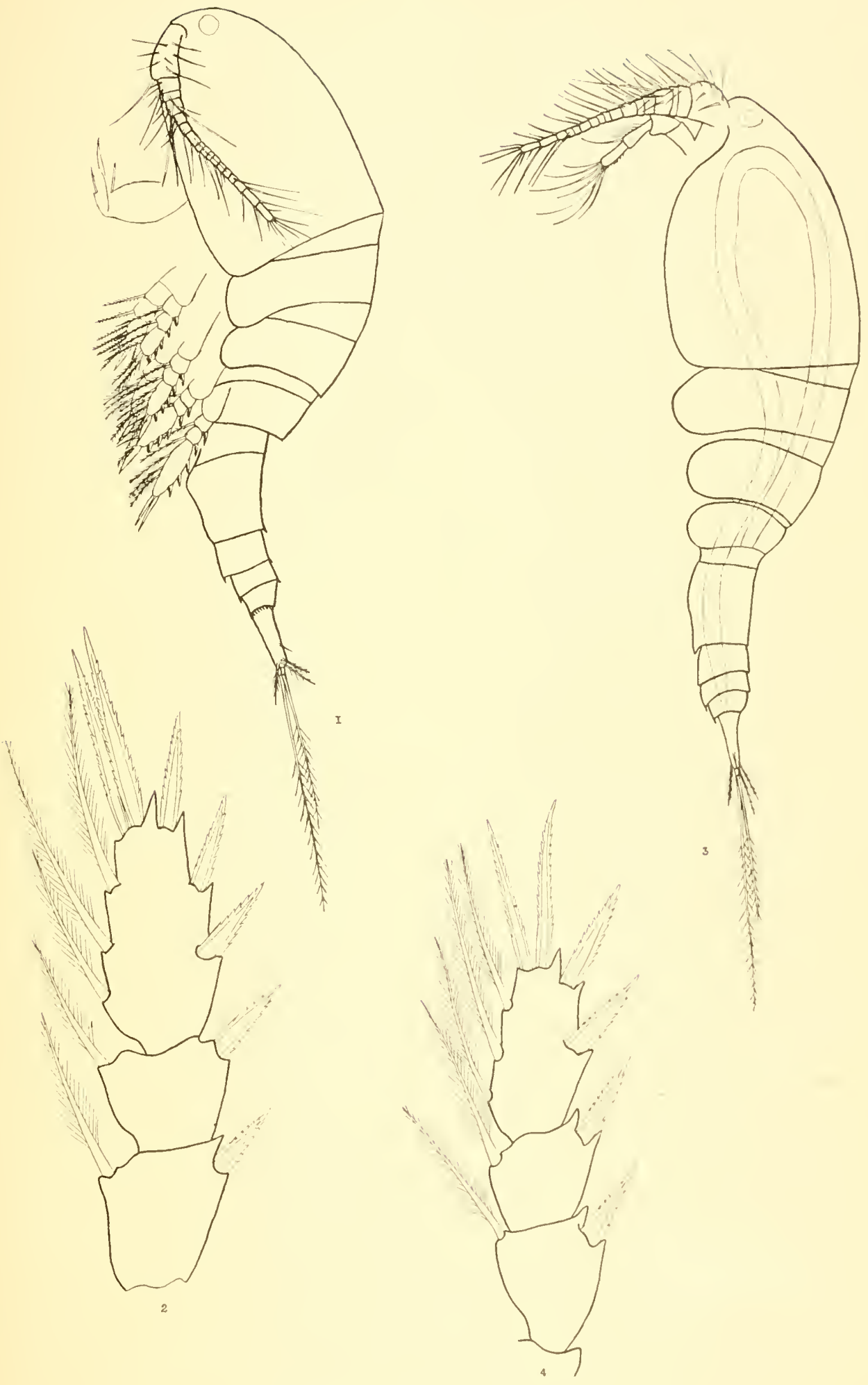

PLATE IX

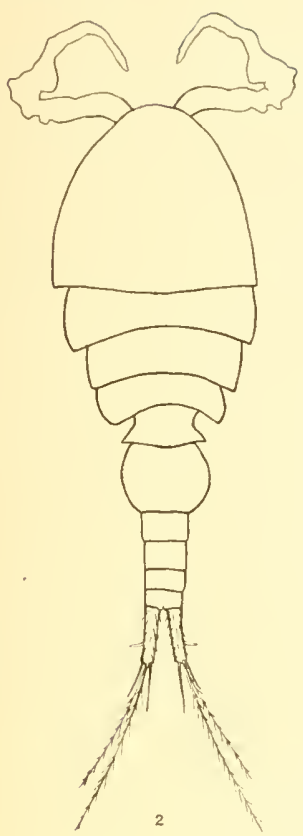

CYCLOPS VIRIDO-SIGNATUS

E. F. BYRNES

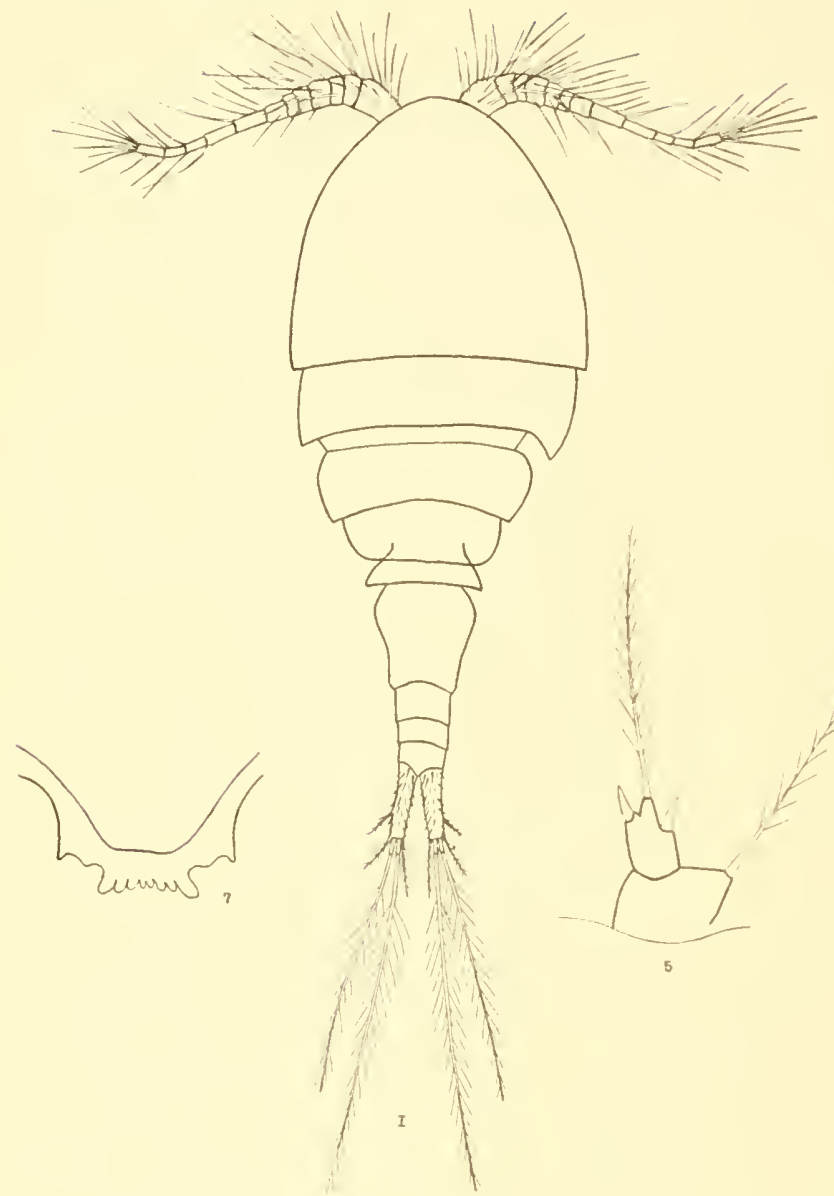

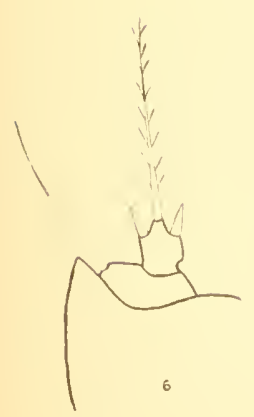
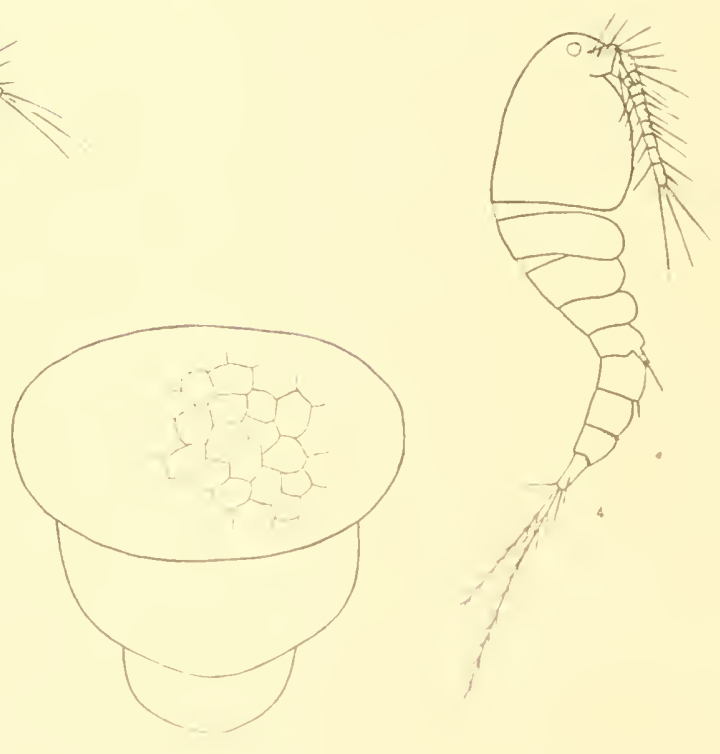


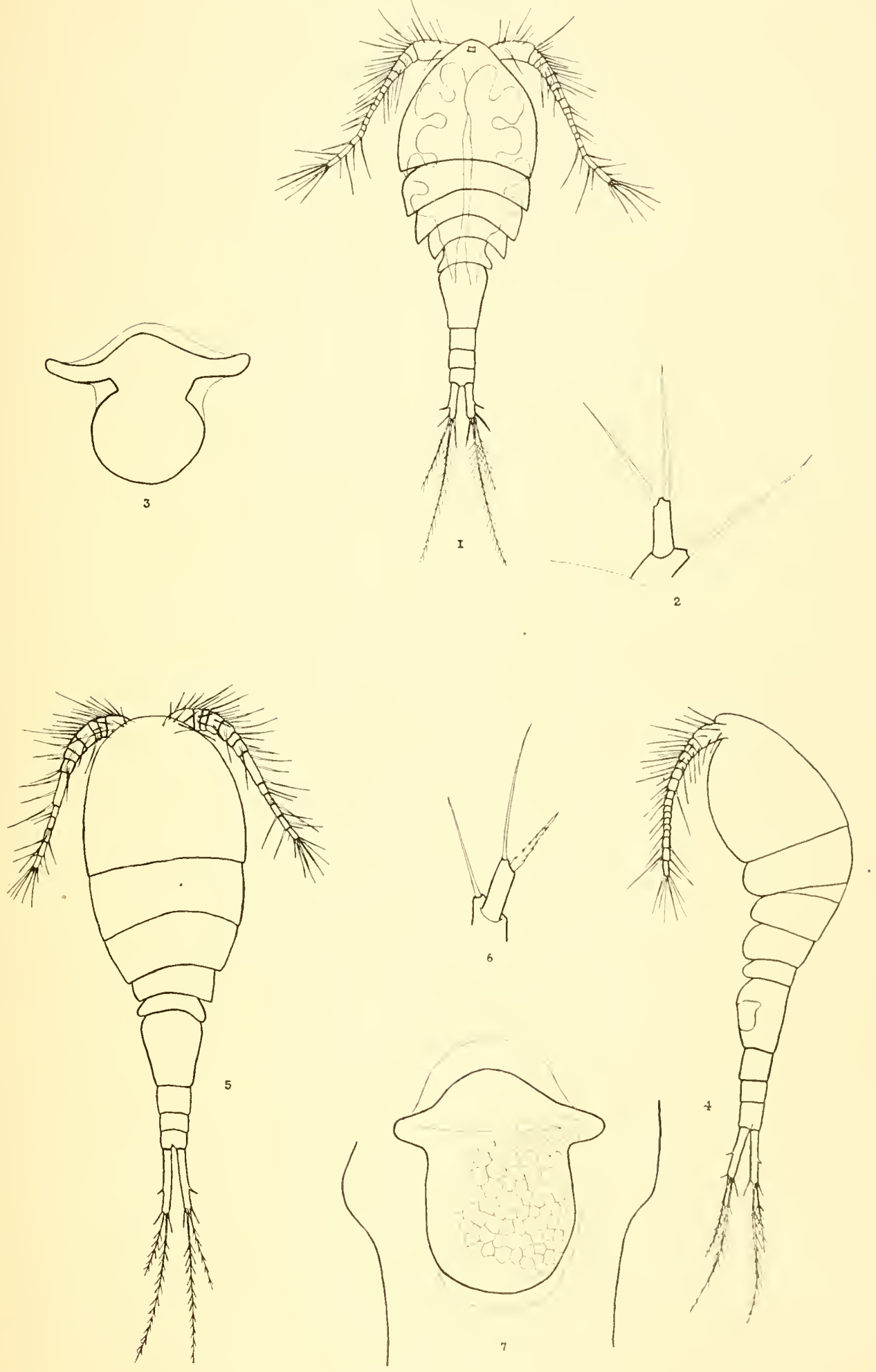


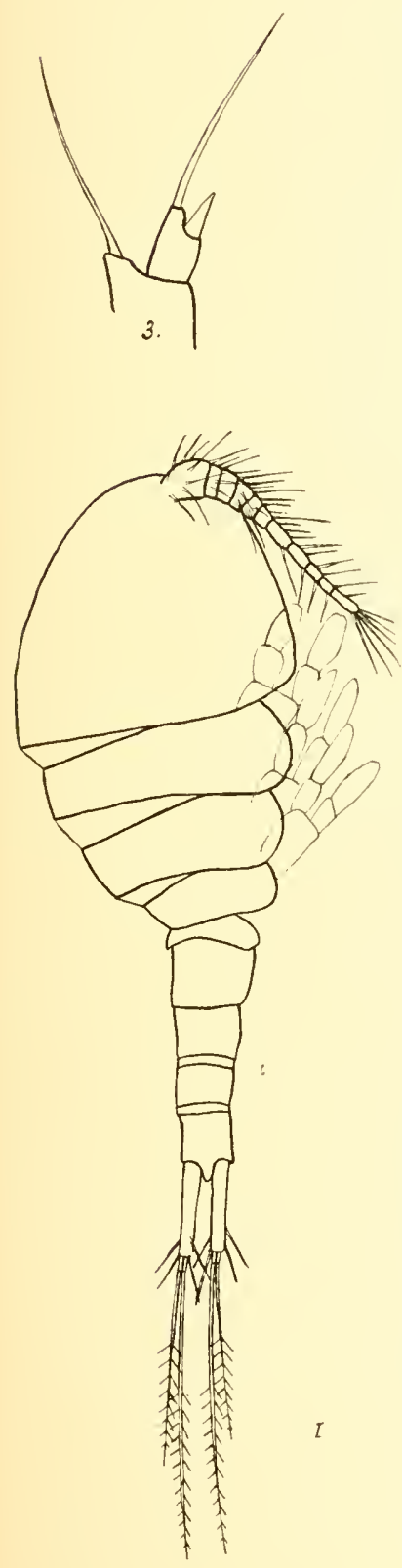
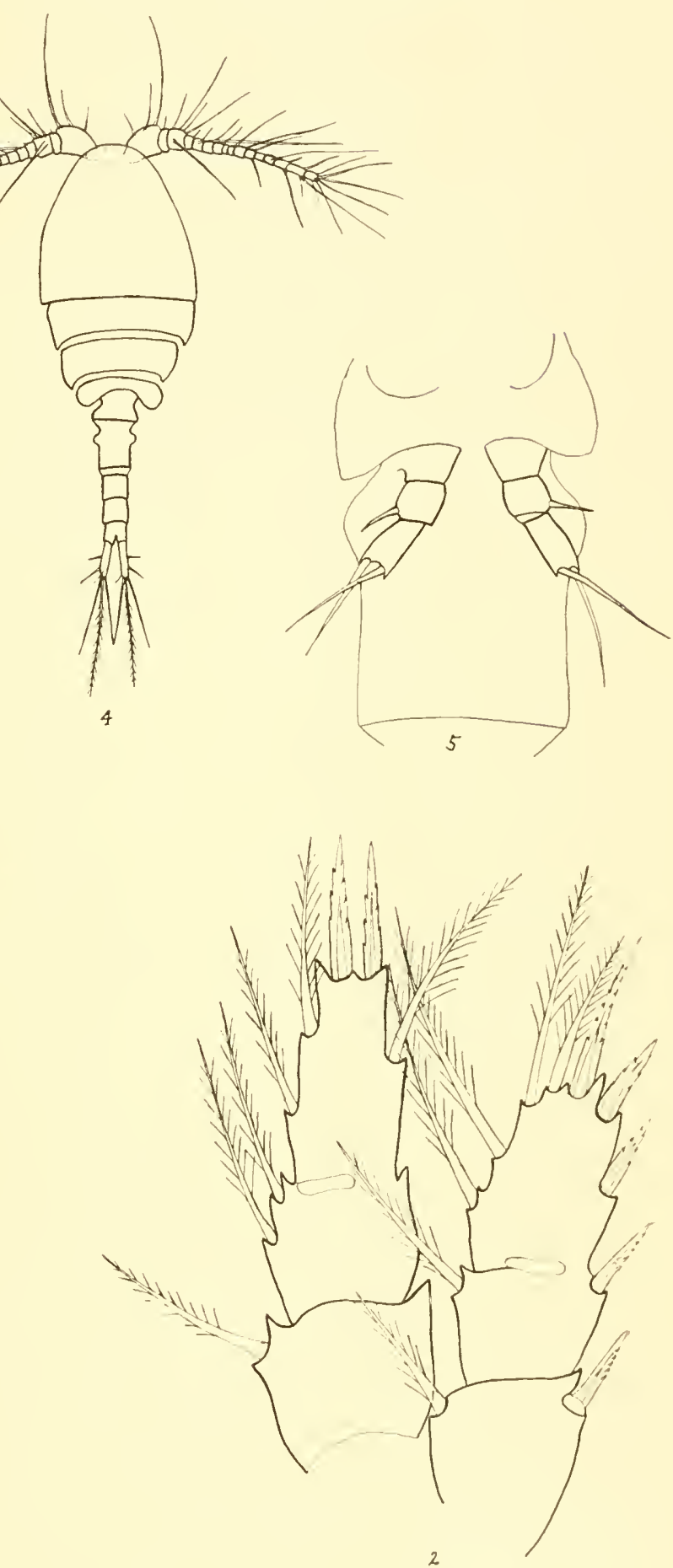


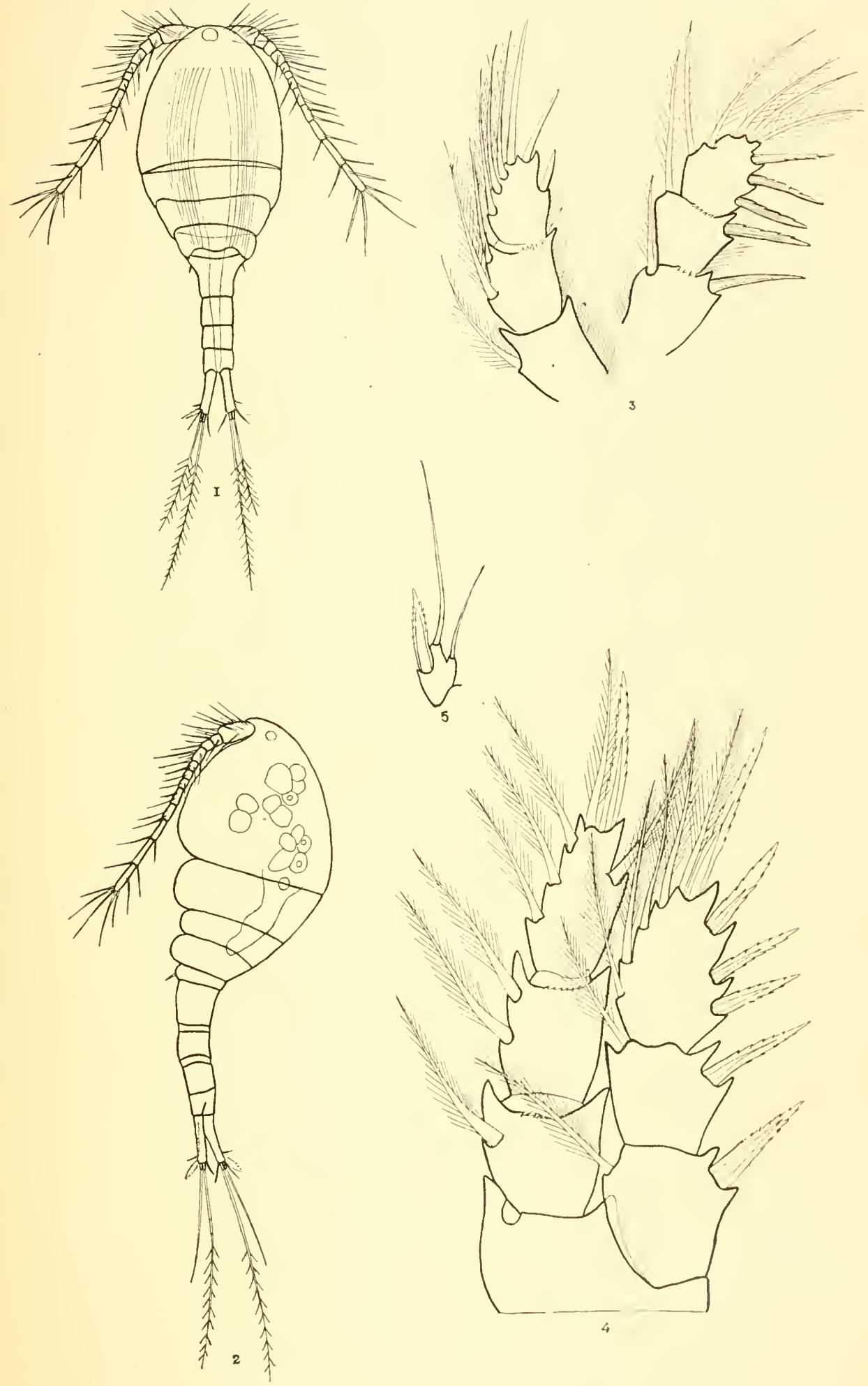


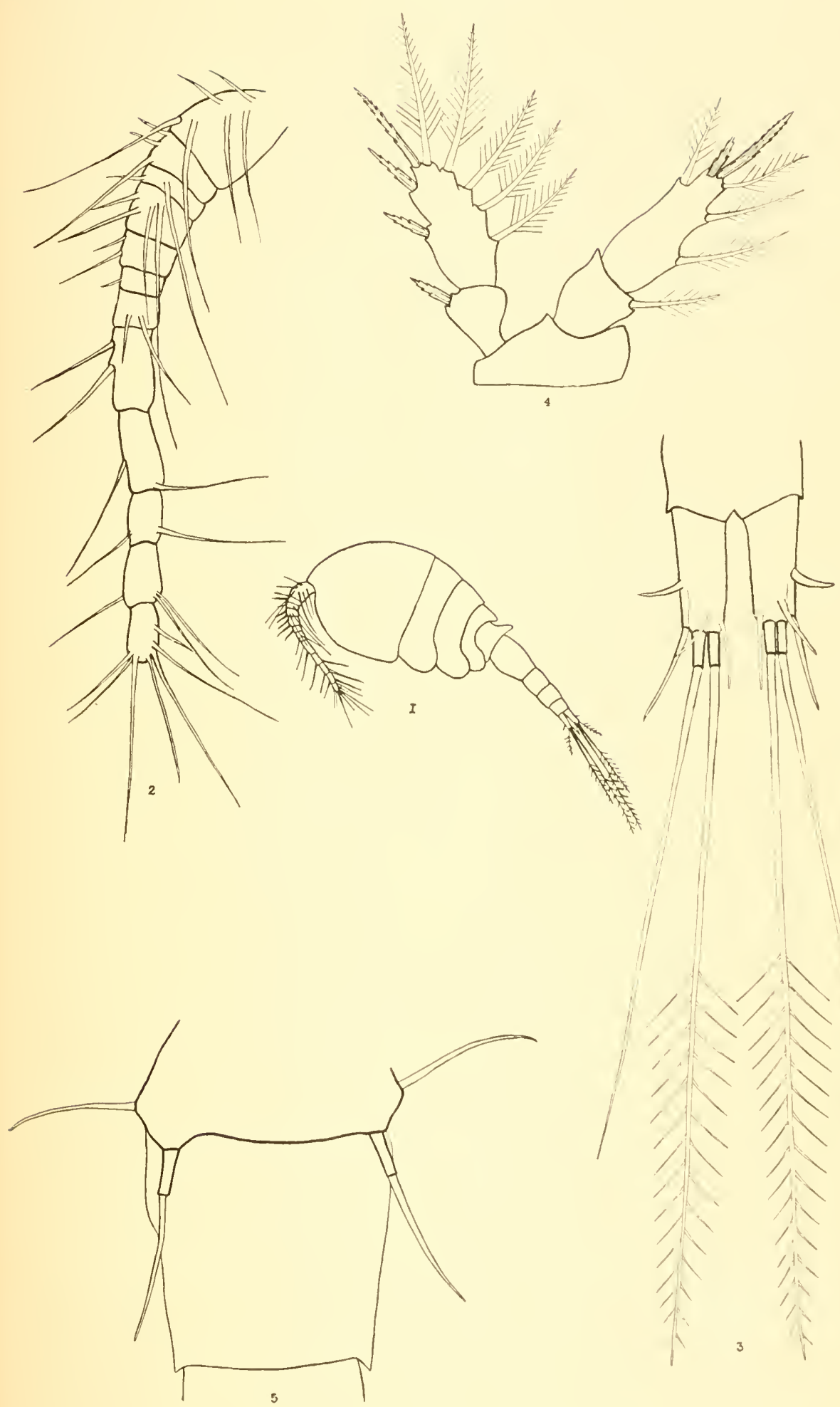


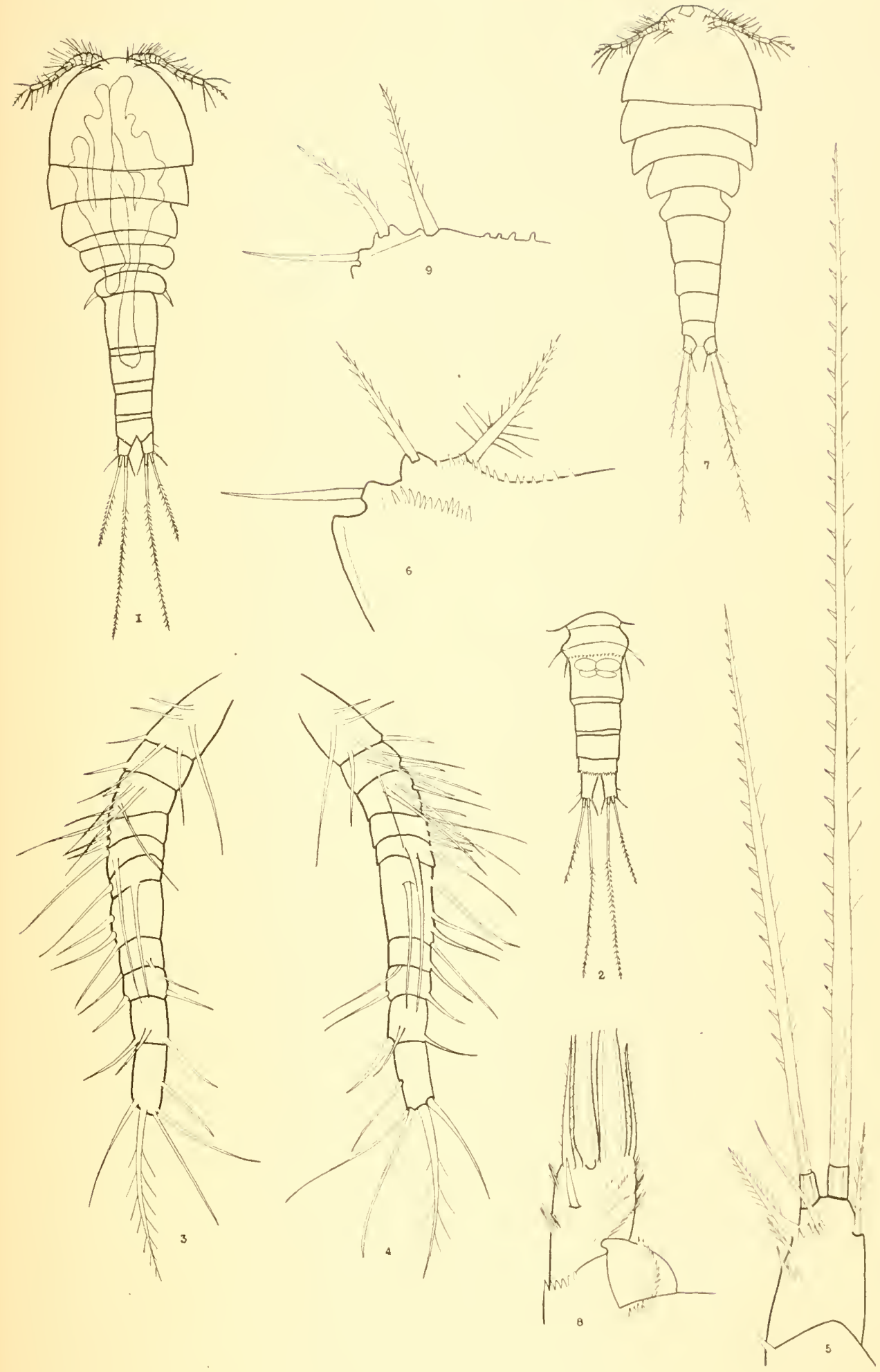



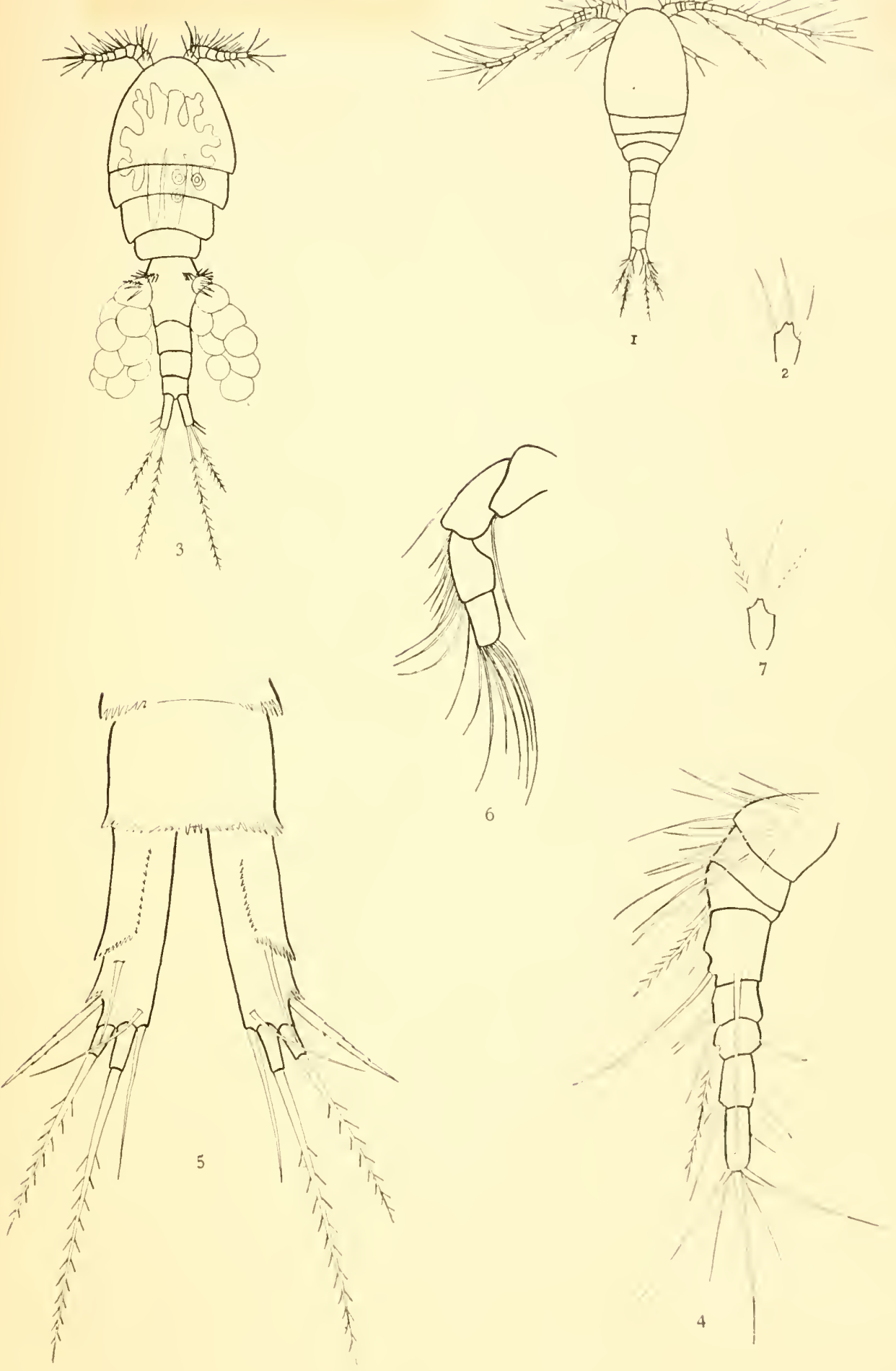


